\title{
The Sense of the Universe: towards \\ a New Phenomenological Turn \\ in the Dialogue between Cosmology and Theology
}

\author{
Alexei V. Nesteruk* \\ University of Portsmouth \\ Lion Gate Building, PORTSMOUTH, PO1 3HF, UK
}

Received 20.09.2014, received in revised form 14.10.2014, accepted 12.12.2014

The article discusses the problem of interpretation of the universe as a whole in the context of the modern dialogue between science and religion. It is argued that the very possibility of cosmology and theology imply each other. Thus humanity becomes the central problem of the dialogue because of its ambivalent position in the universe as being an organic physical being on the one hand and the articulating consciousness of the whole universe, on the other hand. On the basis of asymmetry in relation between theology and cosmology a methodology of a theological treatment of cosmology is suggested as being based in the irreducible primacy of the event of living with respect to any possible representation of the universe. A phenomenological methodology of "deconstructing" the ideas about the universe is suggested with the aim to disclose the source of these ideas in human person.

Keywords: cosmology, dialogue, faith, free thinking, humanity, person, religion, science, theological commitment, universe.

Research area: philosophy.

\section{Introduction}

This paper proposes a new methodology of appropriation of modern cosmological ideas in the context of the nowadays popular dialogue between science and religion. It does not aim to compare contemporary mathematically arranged cosmological ideas with the theologically expressed experience of communion with God. The author believes that it would be incongruous to bring the cosmological views of the Fathers of the Church (which historically had been rooted in ancient Greek philosophy and astronomy) into correlation with the experimental and theoretical results of modern cosmology. Similar to this, it seems doubtful to conduct a comparative hermeneutics of the scriptural texts with modern writings on cosmology in an attempt to reveal some linguistic parallels: such a comparison would exhibit an arbitrary approach which is dictated neither by the needs of theology nor by the logic of science. The author develops his argument starting from the premise that there is a fundamental asymmetry between cosmology, as a definite form of activity and thinking, and that philosophico-theological consciousness which exercises its reflection upon cosmology. This asymmetry consists in a simple fact that although philosophical and theological motives

(C) Siberian Federal University. All rights reserved

* Corresponding author E-mail address: alexei.nesteruk@port.ac.uk 
enter implicitly any speculations on the universe, cosmology, as a scientific discipline cannot explicate these motives. The motives which are implied here enter our discussion as a certain attitude of consciousness which is determined by an ambivalent position of humanity in the universe, that is, on the one hand, being included in or contained by the universe, and, on the other hand, containing the universe as a representation and articulated reality within consciousness.

It follows from what has been said that a "comparison" between theology and science has sense only in the context of the problem of man as a carrier and expositor of cosmology as well as theology. It is, humanity that becomes a core element of the dialogue between science and religion; for it's in human being that the split of intentionalities of consciousness towards the objectivised and alienated world on the one hand, and towards the underlying foundation of the world, as well as the very articulating consciousness of this world, that is God, on the other hand, takes place. Theology and cosmology turn out to be intertwined simply because of the paradoxical position of humanity in the universe, being a physical and biological mechanism in this world, and at the same time, being a carrier of the Divine image not of this world.

Let us elucidate this last point. If one poses a question: "Why does theology need cosmology?", a simple empirical answer comes to mind. Since the very possibility of theology is determined by the actual existence of those to theologise, that is human persons, then in order to theologise one needs necessary physical and biological conditions for existence of these persons, which, as it is not difficult to comprehend, are rooted in cosmic conditions. It is cosmology that explicates these necessary conditions. From here on, one infers that any theological proposition, expressing experience of the Divine in the world implicitly contains in itself truth about that very world, where this experience occurs.

If one inverts the above question and asks: "Why does cosmology need theology?", one can respond to it through the following observation. Cosmology predicates the factual state of affairs in the physical universe without clarifying the sense of the sufficient conditions which are in the foundation the very possibility of knowledge and explication of the universe by human persons. Theology interprets this point by pointing out that only human beings have the rational ability to transcend the boundaries of the physically finite, including their bodies and the attuned living space, and integrate in their consciousness the sense of the infinite and eternal. Consciousness and reason characterise the human condition in the universe and cannot be explained through their reduction to the physical thus remaining an inexplicable mystery whose elucidation and interpretation is possible only through the recourse to theology of the Divine image in man. Correspondingly any cosmological proposition about the world becomes implicitly imbued with theology of the Divine image.

The same can be expressed philosophically. Since theology as well as cosmology are products of one and the same human subjectivity, that is two different types of the living experience and self-comprehension of its place in being, no existential contradiction between these two types of experience is possible. The contradiction appears only when experience of living is reduced to the phenomenality of objects where the presence of the human insight in the world is lost and the structure of the world is infolded from the position of some disincarnate subject. What is missed in this treatment of the world is that the very possibility of such an objective picture of the world is still rooted in the innate 
"simultaneous synthesis of the universe" as an inherent feature of consciousness of a physically real person.

A careful insight into cosmological ideas allows one to discover the presence of the human subjectivity even in those conditions when cosmology attempts to "crush this subjectivity under the pile of astronomical facts". Here a genuine human theological fidelity is revealed when humanity resists this crushing and remains faithful to its intrinsic conviction of the centrality of its position in the universe, of being the centre of disclosure and manifestation of all powers and processes in it. To restore the central status of humanity in the universe through an existential and phenomenological "deconstruction" of cosmology will mean to uncover the hidden theological commitment in cosmological research.

Such a methodological position with respect to the elucidation of the sense of cosmology positions the philosophy employed as not a "neutral" form of thought, but as imbued with existential meaning and theological connotations for a philosophical reflection as well as scientific theories are "inserted" (bracketed in) in experience of existence, that is experience of communion with God as the source of this existence. Thus this methodology aims to conduct the philosophical analysis of those logical operations of the human mind in research of the universe from within a hidden philosophico-theological "obviousness" which is essential to all acts of consciousness, including scientific ones. Starting from this obviousness cosmology is explicated as a certain way of interrogating the reality of the world as well as that of human beings themselves. Such a philosophically and theologically "enlightened" treatment of cosmology, despite its sheer deviation from main-stream science is, in our opinion, very timely because it elucidates not only an existential sense of what cosmologists speak of the universe, but also the sense of what they are speaking of themselves, that is of human beings incarnate in this universe and capable of speculating about it. Thus, the main interest of this article is not so much in the sense of physical realities which cosmology attempts to constitute, but in the ways this constitution originates in the anthropological and psychological aspects of humanity's existence which express basic anxieties of existence, its theological mystery. Our interest is not in describing of that which is in the universe as if this description would be self-evident and not needing any further analysis, but in investigating of how this very description became possible. This is a philosophical objective which cannot be fulfilled without recourse to theology. Correspondingly, the search for the ultimate foundations of cosmological knowledge cannot avoid a certain "theological commitment" which is related to the stance on the nature and essence of the knowing subject ${ }^{1}$. At the same time, the enquiry into those original conditions in the study of the universe without which this study would not be possible explicates this hidden theological commitment. The analysis of the conditions of knowledge is called in philosophy "transcendental". This analysis deals with two fundamental issues: 1) the intrinsic interlink between human consciousness and the possibility of sensing, judging and reasoning about the universe; in short: the universe can be presented in thought and knowledge only as constituted within certain transcendental delimiters related to the structures of embodied subjectivity; 2) it is because of the physical and epistemological incommensurability between the universe and human beings, that the universe always remains a transcendent background of any transcendental knowledge. The "relationship" between the universe and human beings is established on the principles of freedom, that is free thinking (related to what Kant called the 
faculty of reflective judgement, and theologians call free will). This freedom implies that the universe and humanity interact on the ways of their mutual constitution: the universe is a never accomplished mental creation whereas human subjectivity is the self-correcting structural unity of apperception, the unity which originates in the thought (intuition and imagination) of infinity of the universe. A theological stance in this transcendental analysis is that humanity remains free and responsible in its thinking of the universe, because this thinking implies free action, free judgement and choice of theoretical options, which is not subordinated either to the rigidity of the structures of subjectivity, or to the material content of the universe. A theological stance is the possibility of transcendence in cognitive actions, the transcendence either as longing for the incommensurable content of the universe, or as a resistance to any forms of thought which position humanity as part of the cosmic determinism, denying its ability to avoid the dissolution and crush by the mounting number of facts about the universe ${ }^{2}$. Finally, a theological stance in the transcendental analysis of cosmology, is the commitment to the view that the very facticity of the subject of transcendental knowledge, that is a human person, originates in and through communion with the divine, as the giver of life and provider of its image.

The study of cosmology through the prism of the philosophically and theologically weighted mind is not in tune with the modern way of treating the real in terms of the palpable and scientifically representable matter. In this sense, such a study is untimely, that is out of tune with the present, in the same way as philosophy, which deals with the phenomena (in our case the universe) that cannot encounter any immediate response from wider humanity, is untimely. Thus philosophical enquiry in cosmology imbued with a theological commitment reveals itself in an autonomous existence such that it makes things more difficult and complicated. However, here lies the advantage of a philosophical interrogation of cosmology as an autonomously functioning consciousness above and beyond that massconsciousness which functions in the natural attitude. Sceptics and nihilists, whose presence among intellectuals bears a sign of our times, can raise a disarming question as to whether it is worth doing at all: "What for to study the foundations of the universe?", or, correspondingly, "What for to understand the sense of humanity?" The response to these questions comes from the definition of philosophy as love for wisdom (philo-sophia) and truth (aletheia) which imply love in general as a major characteristic of the human condition understood theologically. To enquire into the sense of the universe means not only to know it, but to be in communion with it, to love it. The philosophically and theologically oriented cosmology is not "knowledge" achievable and ready to use. This philosophical cosmology belongs to the realm of those perennial aspects of the human quest for the sense of being which can be addressed only in the rubrics of the so called negative certitude ${ }^{3}$ pertaining to the long-lived traditional theology which does not provide us with a definite discursive judgement on the existence of God and what God is; this question drives the human reason only to one possible answer: it is certain, but this certainty is negative, so that one cannot answer this question in rubrics of reason alone. In similarity with theology when cosmology dares to predicate the "universe as a whole", or "multiverse" (the plurality of the worlds), the outcome of this predication does not resolve the present scientific uncertainty about their actual existence, rather it brings us back to the same "negative certitude" in which no answer to the question of "What?", "Why?" etc. related to the universe as a whole is possible. 
Correspondingly a philosophical enquiry within a theological commitment in cosmology cannot be judged on the grounds of some simplified either scientific or common sense criteria. Philosophical cosmology within a theological commitment characteristically contributes to understanding and formation of humanity through its interaction with the universe. It represents cosmology as a general strategy of acquisition of the world, the strategy which manifests the ongoing incarnation of humanity in the universe, or in rather theological terms, the "humanisation" of the cosmos. In this sense, philosophical cosmology within a theological commitment is directly related to philosophical anthropology as well as to the discourse of personhood. Both of them are concerned with the ancient question raised in Greek philosophy "why is there existence rather than nothing?" Contemporary physical cosmology attempts to respond to this question, however its forms of thought remain intrinsically unadjusted to this type of interrogation. Saying differently, cosmology is content with what it says in physical terms and what one says about it as it exists. However, to understand the sense of cosmology one needs to establish a new type of "questioning of cosmology" in which thinking is evolving beyond what was stated by cosmology itself. Here one needs an "enlightened" reason, or, as it was expressed by Nietzsche, a "great reason" which, on the one hand, is associated with the embodiment in flesh of the universe and which would represent cosmology as a specific way of appropriation of the world. On the other hand this "great reason" is related to the Divine image in man, which humanity attempts to restore and fulfil, making thus the process of the humanisation of the universe its communion with the Divine. In this sense, any philosophical cosmology confesses a free type of thinking which is not constrained by the findings of the scientific and thus transcends physical cosmology by bringing it to the next circle of understanding the essence of being and humanity. The issue is not to think of the essence of cosmology, which would be equivalent to being restricted to its contemporary forms, regardless as to whether we judge it positively or negatively. It is important to realise that by questioning cosmology philosophically and theologically we overcome its seeming neutrality with respect to us thus advancing our understanding of the very being of cosmology as being in us. Cosmology is acting in producing its theories, but it does not think in a philosophical sense (compare with a famous Heidegger's assertion that science does not think). The sense of cosmology can become enlightened only when the gulf between its particular theories and human thinking in general is realised.

To establish the sense of cosmology starting from cosmology itself, this cosmology must evolve in a radically reflective, that is, ranscendental mode, that is, in fact, to become philosophy. The sense of its theories can be grasped only within a critique originating in experience. And there is the realm of transcendental self-experience which can be established through a method of phenomenological reduction. This reduction aims to overcome a "natural naïveté", that is, a belief in that cosmology only deals with the things of the outer world. Its ultimate objective could be seen as questioning the neutrality of cosmological propositions (their invariance) with respect to specific historically contingent events of knowing. To remove the elements in this contingency would imply the return to those irreducible certainties which would represent the universe as pertaining to the essence of one's conscious life. It is from this life, with its mundane experiences, that the universe is constituted on the basis of its phenomenality. Life is not anymore understood here as an empirical psycho-physiological life which belongs to the universe, but as the transcendental self- 
apprehension which comes forth and from within which the universe emerges as its intentional correlate. By inverting this last proposition, one can assert that it is through cosmology that transcendental subjectivity is revealed as overcoming its own incarnate boundaries. Indeed, by stripping off the layers of the physical and biological one comes to discover that the universe as a whole appears as an intentional correlate of transcendental consciousness. Thus "putting out of play" the contingent aspects of the universe brings cosmology to a discourse of the transcendental subject, as that centre of disclosure and manifestation of the universe through which the latter acquires its own "voice"4.

However, even this transcendental reduction does not guarantee that we do not fall into a "transcendental naïveté". This naivety amounts to thinking that reality presupposes the transcendental subject as that pre-given contexthorizon within which this reality unfolds. But this transcendental subject still functions as an embodied creature, that is in the world of physical things. However, the very physical things do exist for this subject only as constituted by it. With regard to the universe as a whole, the situation is different: its alleged totality cannot be constituted by the subject but, vice versa, the subject itself is being constituted by the universe (not in a trivial physical sense). In order to clarify this thought one must remind the reader that cosmology, as a historically concrete science, is capable of making its claims on the structure and evolution of the universe within the limits of what can be called "positive incertitude", that is that certainty which is local in time and is subject to amendment and falsification. This can be expressed in different words as that scientific conceptual signifiers never exhaust the content of that which is supposed to be signified. "Positive incertitude" in science can be also described in terms of the so called apophaticism (which is well known since patristic times in theology) asserting a simple truth that the appearances of things and constitutions by the finite consciousness deal with a particular, incomplete phenomenality which pertains to objects. With regard to things beyond simple perception and nominations which exceed the capacity of constitution and phenomenality, one can conjecture only in terms of aberrations and approximations. The fact that we can see and speculate about some aspects of the universe does not entail that there are no other aspects of existence than those which are present and perceived by us, but whose presence cannot be affirmed in terms of consciousness and knowledge. A simple physical example of such a hidden aspect of the universe is its dark matter and dark energy that constitute, according to theory $96 \%$ of the overall matter content of the universe. However, the phenomenality of these theoretical constructs is poor: physics does not know what particular particles and field stand behind these constructs. A philosophical example of concealment related to the universe as a whole can be taken as its own contingent facticity, the sense of which cannot probably be disclosed to humanity at all. Indeed, the notion of the universe as a whole, which is claimed to be a subject matter of cosmology, allows one only to have some precarious and incomplete definitions related to the fundamental finitude (spatial, temporal, historical etc) of the subject of knowledge. However, this "positive incertitude" of cosmology does not mean that from a philosophical point of view one must disdain cosmology as irrelevant to any perennial questions. It just implies that the cosmological research has to proceed along the lines of the scientific method in clear understanding that the universe as a whole will never be constituted at all. Then the persistence of cosmology exhibits the courage and heroism of scientists in following their quest for the universe despite the ultimate futility of any hope to have 
this universe as an object of science. The same takes place in theology when believers explicate their experience of God as an open-ended process in a clear consciousness that the true names of the Divine are beyond this age and any denominations. Correspondingly, in cosmology the persistence of research as a purposive activity of humanity is pointing towards its telos, that is the telos of research, which, as such is also beyond this age and any denominations. Here is a fundamental paradox of cosmology, as well as any other science, namely, that its incertitude is that condition of its progress consisting in the unceasing correction and amendment of its results and theories. However, in spite of the fact that a human person cannot constitute the universe, so that the universe saturates its intuition and blocks the reason, this person remains an independent centre of disclosure and manifestation of the universe, resisting any attempt to be crushed by the grandeur of being. In this sense, the "negative certitude" in relation to knowledge of the universe, turns out to be a constructive certitude of constituting the human subject. By interacting with the infinity of the universe human persons form themselves: in the measure that humanity is incapable of constituting the universe as a whole, the human person is constituted by the universe as an "object" of humanity's constant interest and anxiety of its own position in it. This means that the transcendental subject which appropriates the universe into the sphere of its own subjectivity and which is destined to carry out the phenomenological reduction with the goal of revealing the immanent belonging of the universe to consciousness of the subject, is the forming and changing subject, who is formed and changed through this very appropriation. One can summarise by saying that the understanding of the sense of cosmology implies the understanding of the formation of self-consciousness of humanity's position in the universe subject to one important condition: the cosmological picture does not diminish the place of man in the universe as the centre of its disclosure and manifestation. The more cosmology proves that human being is no more than a speck of dust in the universe, the more the human person resists this by defending the sense of its existence. That which has been said partially explains the sense of what we asserted earlier that the human "I" is constituted by the universe.

But the shift of the centre of cosmological enquiry into the life of transcendental subjectivity still retains the same perennial question of the facticity of this very subjectivity. If it is claimed that the characteristic feature of personal existence, that is human hypostatic being, is its ability to resist scientific tendencies of denigrating humanity by dissolving it in the natural and cosmic, and, hence, to understand the cosmic conditions of the human existence only as the necessary ones, then the question arises as to what is the ground and foundation of the contingent facticity of hypostatic existents, that is persons, that is where do the sufficient conditions of the human existence come from? Certainly one can take a classical existentialist's position which makes this last question devoid of any sense, for one cannot abstract from the already present event of life. However, this stance is unsatisfactory for a theologically inclined mind, who wants to see in the very fact of conscious existence the manifestation of truth (aletheia) in an absolute sense. So that the acceptance of conscious existence as an absolute reference point of any further philosophising implies belief in the truth of existence. Thus, the knowledge of the universe as unfolded from within the human subjectivity is by its essence committed to a simple existential faith. For a sceptical scientist or for a modern atheist it would be problematic to proceed from existential faith to religious faith, that is to the conviction that truth has foundation 
in God, for any reference to the Divine would imply transcendence, principally impossible in science and prohibited by the very essence of the phenomenological reduction ${ }^{5}$. However, and this is our main point, the very reduction as well as the functioning of consciousness will be impossible at all if the reference to the source of its contingent facticity would be eidetically removed. In such a case, the removal of God as the foundation of consciousness would lead inevitably to a suggestion that there must be another, transworldy foundation of this consciousness which would be analogous to the idea of God, that God which was previously bracketed out. Correspondingly we return back to the assertion that any hypothetical reduction of God would imply the cessation of functioning of consciousness itself. This is one of the motivations of contemporary phenomenology to argue that even if facticity of consciousness cannot be justified, it can at least be explicated through dealing with the saturated phenomena which, in a way, constitute this consciousness ${ }^{6}$.

To understand the sense of cosmology within a theological commitment is thus to understand the existential sense of the universe, or, to be more precise, to "understand" what it means to think of or commune with the universe. What could it mean the thinking of or communion with the universe in the conditions of a scientific and technological age in order to avoid this thinking being enslaved by the sphere where knowledge is operated according to some social, but still historically contingent standards? Correspondingly, how could we dress this thinking in words while avoiding all cultural superstitions which engulf our language? And even in the case where we believed that we have achieved such a goal, could we expect any recognition of that form of thinking which intentionally extends beyond the view of the universe which is framed by varieties of scientific projects, conference discussions and numerous publications? All these questions implicitly presuppose that the scientific way of thinking of the universe does not cover the fullness of our communion with the universe which is concealed in the very fact of our existence. This concealment follows, for example, from the fact that humanity is able to interact not only with the physical world of corporeal objects, but also with the realm of intelligible forms, to which cosmology can attest only indirectly. To think of the universe is thus to explicate the sense of the universe on existential grounds, where our understanding of the adjective "existential" follows from the sense which was asserted by existentialists in the $20^{\text {th }}$ century, namely, that human life and existence is the primary and unquestionable metaphysical fact from which the whole reality is unfolded ${ }^{7}$. And this, as we have mentioned above, contributes to the perennial issue of how to think of humanity. Thinking of the universe in existential categories thus implies the extended vision and perception of the universe, which, in words of the $7^{\text {th }}$ century Byzantine saint, Maximus the Confessor, is the makro-anthropos, that is that which was created in order to be humanised.

To think of the universe on the grounds of existential communion entails freedom of such thinking. It does not necessarily imply the overthrowing of scientific authority in the questions of physical cosmology: it implies that cosmological theories and hypotheses can be interpreted not as propositions about outer realities but as movements of the human heart and spirit which reflect a fundamental anxiety of existence. In this case the universe is perceived as a certain whole, whose partial phenomenality is explicated by science. This whole includes not only the physically fragmented or united cosmos, but it includes the infinity of human life (the infinity of relations of human beings to created existents) in the universe. Correspondingly all accumulated forms of knowledge, established in history to this very date, are merely pieces and 
moments, temporary and provisional sketches of the immensely mysterious phenomenon of personal beings. The "non-technological" thinking of the universe, even if it will not be able to reproduce this "whole of the universe" (which was, however, attempted in works of art and poetry) and hence will remain no more than a symbol rather than reality, can receive its justification in a deep hope, that through this thinking we learn something of ourselves which has never been present in our vision of all. Being an intentional thinking, thinking of the universe as a whole brings that one who thinks beyond any conditional objectification and positivity which could seem as that which fulfils this thinking. In a way, thinking of the universe is transcending the limits of thought at all which requires from the enquirer exceptional discipline, courage and humility in front of the fact that the task will never be fulfilled and that they are ready to learn of themselves something which could shatter the image of their own "I"

By thinking of the universe as a whole, we attempt to explicate our intrinsically ambivalent existential situation, being a part of the universe, in its particular time and space, and at the same time being at "that" paradoxically central "nowhere" from which the wholeness of the universe is unfolded. Some cosmologists can object to this by saying that in terms of time we are living in a very special era in the universe, that it is only now that it is possible to detect the universe's evolution, its origin in the Big Bang etc ${ }^{9}$. The universe as described by specific cosmological theories is not contingent from the point of view of these models. However, from the point of view of the very possibility of such a description, that is from the point of view of the contingent facticity of life of knowing persons, it is still contingent. The pole of "nowhere" remains intact simply because cosmology, which deals with the physical background for existence of embodied human persons (that is, its necessary conditions) is not able to shed the light on the nature of the sufficient conditions of existence of intelligent observers and theoreticians of the universe. It is this pole of "nowhere" in thinking of the universe that deprives this thinking of any essential historical goal, which could be placed at the service of any intellectual or social-political economy, if it is not related to the saving ideals of Christianity. Being engaged in thinking of the universe as a whole we are immersed not so much into the present of the scientific discourse of the universe but into the present of thinking itself. And this present is dictated not only by the advance of contemporary physical theories of the universe but to a great extent by the advance of thinking per se, that is its free philosophical mode which is not subjected to the logic of the already known but follows that which Husserl called humanity's "infinite tasks" (Husserl, 1970, p. 279). Here it is appropriate to quote K. Jaspers, rephrasing a little his text, that our historical consciousness of the universe, in spite of being a temporal phenomenon, is a "freeflying" consciousness without "any ground and original point accessible to knowledge, ultimately rooted in that source which is always and necessarily present in ourselves" (Jaspers, 1982, p. 77). This type of thinking, flying away from mundane realities and technological delimiters, will reveal deeper and clearer the fact of our, as Heidegger termed it, "planetary homelessness" (but still centrality) which pertains to the present intellectual, social and political unpredictability of the human condition. One must, perhaps, amplify this point by using the term "cosmic homelessness" implying the lack of understanding of the human place in the whole universe. We are homeless because the universe is infinite, and in spite of some claims of our centrality in the universe, we still do not know our place in it, that is we do not know scientifically the grounds of our facticity in it. What we know for sure, however, 
is that it is us who articulate the universe, so that, perhaps, as some claim, we are in the centre of the universe, but the question of "where" this very centre ultimately is, remains in the field of perennial certitudes négatives.

While Jaspers could say that the realisation of "cosmic homelessness" (as the denial of the historical consciousness) becomes "the metaphysical consciousness of being (Sein), which being constantly present, must become evident in true being (Dasein), as if in eternally present" (Ibid.), according to Heidegger, our "cosmic homelessness", that is inability to answer questions about own essence, drops a shadow of doubt with regard to being of the universe itself (our "cosmic homelessness" can be qualified as non-being $)^{10}$. Then it is from this perspective of our own finitude, mortality, non-attunement to and incommensurability with the universe that one must have the courage to think of the universe in order to assert ourselves. However, this assertion of ourselves has a particular spiritual importance only for those who still value the humanity of the humans, naturalness of nature, justice of the police, and other perennial values which crown man in the centre of the world, for whom this world is given to fulfil the "infinite" task of finding its destiny in the union with the Creator of the universe and the giver of life. Thinking of the universe leads one to thinking of God and it is in this that this thinking follows a hidden theological commitment.

It is not difficult to see that thinking of the universe as if we think of the thinking itself at present, allows one to establish certain liturgical connotations as articulations of the overall temporal span of the universe, its past, present and future in conscious acts which fight oblivion which pertains to the eternal flux of being. When articulated, the universe is being remembered not only as its realised past. The question of active remembrance of the universe, is the question of such an understanding of human life in which past, present and future are not considered anymore as signs of the all-annihilating Kronos, but as being able to be integrated through remembrance in the image of humanity living in tension between a thanksgiving for existence and a hope for its nontransient sense ${ }^{11}$. To study the universe does not mean to establish a simple vision of the world on the grounds of mundane curiosity or personal needs. It rather forms a vision of that "selfhood" of the universe (as the makro-anthropos) which is truly important for one's existence and which brings to unconcealment of the truth of the human existence. When we speak of the "self" of the universe, we do not presume that it does have hypostatic features but, allegorically speaking, humanity by looking at the "face" of the universe, sees this "face" as looking at themselves, and it is this all-penetrating "glance" of the makroanthropos that forms the image of humanity as its ability to see the infinite in the finite. In a certain sense human beings, as they are sustained by this last mentioned glance, want to respond to it thus asserting not only their longing for the commensurability with the universe, but also their infinitely transcending lordship over the universe resisting their cosmographic insignificance and a fear of being crushed under the weight of astronomical facts. Pascal compared man with reed, thinking reed, in the universe, the weakest but thinking element in the chain of being, so that a drop of water can kill a man and the universe does not need to arm itself in order to crush man. "But even if the universe should crush him, man still would be more noble than that which kills him, since he knows he is mortal, and knows that the universe is more powerful than he is: but the universe itself knows nothing of it. All our dignity, then consists in thought. It is through thought alone that we have to lift ourselves up, and not through space or time which we cannot fill"' 12 . 
The freedom in thinking of the universe, however, has its delimiters; this freedom does not imply an arbitrary rule in this thinking, first of all, its spiritual arbitrariness. When we brought the reader to the thought that thinking of the universe is accompanied by thinking of God, we were conscious that there always was a danger of a "divinisation" of the universe. Here one means not a naïve and outdated pagan perception of the cosmos as a living organism or the place where gods corresponding to different astronomical objects are abiding. It is a much more refined form of spirituality which is implied here, rooted in the sense of immanence of the universe, its infinity as an actually existent mystery which does not need any reference to the personal transworldly ground of the world. Cosmology in this case becomes a spiritual exercise since it is based in the life of the spirit; however, the demarcation between such a "spiritual cosmology" and theological commitment arises at that point when human beings make a distinction between the universe as a necessary condition of their existence (that is an immanent medium of their inhabitation) on the one hand, and God, as an underlying transcendent sufficient ground of the very possibility of life and vision of the universe on the other hand. Speaking theologically, there is here a difference of a soteriological order, so that to avoid arbitrariness in thinking of the universe means to follow a theological commitment referred to the salvific sense of the universe. A difference of a soteriological kind was pointed out by V. Lossky when he commented on the place of cosmology in the writings of the Fathers of the Church and, in particular, in the case if cosmology looses the sense of the centrality of humanity in the perspective of salvation, for example: “... copernican cosmology, from a psychological or rather spiritual point of view, corresponds to a state of religious dispersion or off-centeredness, a relaxation of the soteriological attitude, such as found in the gnostics or the occult religions" (Lossky, 1957, p. 195). An example of such a dispersion and relaxation of the soteriological attitude can be found in modern "spirituality without God" according to which the immanence with the world going together with no belief at all (for there is nothing to believe in since everything is already here and now), despair (as no hope for anything since everything has already happened) correspond to that a human being is already there, in that reality, which theology names the age to come (Comte-Sponville, 2006). Thus, if the state of affairs is such as it is just described, the question of salvation as a personal spiritual endeavour, as an intensive anthropological transformation (metanoia) may be abandoned as irrelevant. One has everything which is given in its existential concreteness and all this represents an unsolvable mystery with which we have to live and die. In a certain sense, the immanent and infinite universe is treated as that realised "kingdom" of being in which everything is given and one does not need to enquire in the facticity of this givenness. It is at this point that the theological commitment, in contradistinction with the spirituality without God, aspires and breaks towards the transcendent, enquiring into the origins of being in the perspective of the human life and the sense of its coming into existence. Theological commitment revels itself as a concern with the sufficient conditions of the human existence, implying that life is not only a gift of existence, but a gift of relationship and communion with the eternal.

Thus, the delimiters in free thinking of the universe proceed in the long run from the freedom of human beings made in the image of God: all thoughts and articulations of the universe always contain the traces of the divine image in themselves. Even when cosmology proves the insignificance of humanity in the universe, the divine image remains exactly 
because human mind always resists to all attempts to circumscribe its life in rubrics of the natural, finite and transient. Human beings aspire to understand the underlying sense of beings and things not according to their "nature" (which is unfolded in the sciences) but according to the final causes of these beings and things in relation to the place and goals of humanity in creation ${ }^{13}$. This understanding cannot be explicated only through physics and biology. It is based in views on humanity as the crown of creation made in the image of God. And this is the reason why in a God-like fashion humanity wants to recognise all sorts of beings (either simple physical objects or living organisms) not according to their nature that is according to their compelling givenness, but as results of humanity's free will. The image of eternity is retained in any cosmological theory created through the free willing even if this theory predicts the finitude of all actual forms of existence and life. Free thinking of the universe is thinking of freedom of the incarnate human person, brought into being in the Divine image by the will of the Holy Spirit.

Thus, the proposed methodology of studying the relationship between cosmology and theology results in unfolding of theological motives in humanity's perception of existence in the universe, which, on the one hand, outlines human beings as its slaves, constantly "crushed by the ever increasing mass of the astronomical facts", and which, on the other hand, manifests the sense of the human life in the universe by elevating it beyond the world order through a belief, hope and love in the perspective of eternity. This dichotomy between the infinitely small, finite physical existence and the feeling of the light of eternal life was felt by the Fathers of the Church and great mystical philosophers, as their personal vision of the darkness of hell and the light of the Spirit to both of which human beings are constantly turned and in the presence of which they must not only continue their life, fighting cosmic homelessness and despair, but also fight for the finding the sense of themselves and all creation. Theological commitment in cosmology is thus a characteristic expression of the visible and invisible universe as it appears to man in the perspective of communion, that is through the eyes and senses enlightened by the Divine presence. Whereas numerous books on cosmology discuss the role and place of humanity in the universe, our research brings the universe inside humanity, making the universe that mirror of its soul which humanity desperately wants to find.

\section{"Theological commitment" as a different form of the dialogue between theology and science}

There is an element of socio-historical reality which sheds light on the reasons behind the proposed enquiry into the theological commitment in cosmology. First of all, cosmology always (in particular before its $20^{\text {th }}$ century developments) was a part of theism. Cosmological arguments for the finitude or infinitude of the world in space and time were employed as different arguments for existence or non-existence of God. Theistic inferences are still alive and very popular among some philosophers and cosmologists who attempt to use cosmology in both apologetic and atheistic conclusions $^{14}$. However, this dimension of the debate is not our primary concern, because the alternative of existence or non-existence of God is not an option for this research which takes an explicitly theistic stance (that is, theological commitment) on the grounds related to the facticity of human persons who are subjects of cosmological knowledge. Correspondingly we do not analyse cosmology from the perspective of an explicitly theistic stance based on some dogmatic propositions of God's existence, rather we 
proceed cautiously from what we call theological commitment as an existential, experiential mode of communion with God.

Secondly, the topic of research is related to the dialogue between theology and science in general, which became a matter of scholarly discussions in the last 20-30 years. The question is: has this dialogue, in that form as it has been conducted, succeeded so far, that is, did it achieve any results which had impact on both science and theology? The author believes that the negative answer is provided by the unceasing scientific and technological advance (in particular in the exact natural sciences) which continues with no recourse to the dialogue between theology and science whatsoever. All discussions on whether science and theology are in conflict, or in "peaceful coexistence" with each other, do not have existential implications: the problem remains and its ongoing presence points to something which is basic and unavoidable in the very human condition. This net result indicates that the method of conducting this dialogue at present is unsatisfactory in the sense that it does not address the major question as to what is the underlying foundation in the very distinction, difference and division between science and religion as those modes of activity and knowledge which flourish from one and the same human subjectivity. But this type of questioning makes any scientific insight irrelevant simply because science is not capable of dealing with the question of its own facticity, that is the facticity of that consciousness which is the "pillar and ground" of science. Theology can respond to this question from within the explicitly belief-based ground, namely faith in that the knowledge of the world represents natural revelation accessible to humanity because of the God-given faculties. Knowledge is possible only by human persons whose basic qualities are freedom and capacity to retain transcendence with respect to all they assimilate through life and knowledge. In this sense, the universe as articulated reality has existence and sense only in a mode of personhood, which is a divine gift. Since science does not account for the very possibility of knowledge, that is personhood, it is automatically prevented from participation in the dialogue with theology on equal footing. It is logical then to express a doubt on the meaning and value of such an existing "dialogue" with science at all. If one insists on this "dialogue" it becomes obvious that science and theology cannot enter this dialogue as symmetric terms. And if there is no impact of this "dialogue" on logic and development of science, what remains for theology is to exercise an introspection upon science, to conduct a certain critique of science from a position which is, by definition, above and beyond not only scientific thinking, but secular thinking in general related to particular socio-historical and economic realities. Thus, symmetry between theology and science, theology and cosmology in particular, is broken from the very inception. It is this asymmetry that constitutes that approach to the science-religion discussions which we describe in terms of theological commitment. Theological commitment is such a stance on human being which always positions it above and beyond those realities which are disclosed by science alone. It appeals to those meanings of existence which do not compel the recognition of the science in the manner that natural phenomena do. These meanings originate in an innate quality of human beings to long for immortality, that is communion with the unconditional personal ground of the whole world, which humanity names God. And it is through this longing that the universe acquires a certain sense as that constituent of God's creation which makes it possible for human persons to fulfil God's promise for eternal life and communion. Theological commitment is thus existential commitment. 
Thirdly, theological commitment is the reaction to modern atheism. Indeed, in its goals and tasks the dialogue between Christianity and science is to oppose atheism. However, if one carefully looks at how this dialogue has been conducted so far, one easily realises that the existing forms of this dialogue are adapted to that which is imposed by atheism. Such a dialogue turns out to be no more than a reaction to atheism, sometimes attempting to unconvincingly justify the very fact of this reaction. Contemporary atheism manifests itself not only as freedom from historical authorities and tradition (that is the liberation from freedom in a Christian sense) and not only as the unprincipled following of the proclamation "enjoy life for there is no God", that is not only as the worst form of the unenlightened slavery of the Plato's cave in which the signs of the Divine presence are not recognised and the very ability to see them in the world is reduced to nothing. Atheism promotes a cult of immanence, the actually existent infinity of the given ${ }^{15}$, appealing de facto to deprivation of the senses and the vision of the transcendent (and hence to the relaxation of a soteriological moment). Since modern science, and technology in particular, encourage individuals to be transcendent-blind, creating the immanent images of the transcendent, the advocates of atheism appeal to science. By doing so atheism adjusts to the demands and moods of modern time. It is much easier not to deny the presence of the Divine in the world, but to claim that all spheres of the human activity are self-sufficient and do not need any reference to God. Since from a philosophical point of view the question of God's existence or nonexistence cannot be decided at all (the philosophical mind remains in the "negative certitude" with respect to this question), then why should one try to answer it. Would it not be easier to recognise that science, art, literature etc. are just given in rubrics of that which is unconcealed to humanity.
Here atheism reveals itself as secularism, as a kind of trans-ideological läicité , as a servility to nobody's interests, and as a servility to the alleged ideal of humanity understood only empirically, as that humanity which is alive here and now ${ }^{16}$ (it is supposed that this ideal of humanity has in itself a universal criterion of its own definition). To define this humanity in simple categories which overcome racial national and class differences one needs a universal language. It is science which pretends to be such a language; to be more precise, it is that scientific form of thinking which reduces the phenomenon of humanity in all its various manifestations to the physical and biological. It is clear from here that modern atheism as a certain form of the "immanent humanism" is no more than a scientific atheism. However, this atheism positions itself as more aggressive ${ }^{17}$ and sinister, more advanced philosophically and antitheologically ${ }^{18}$ than was the case in the Soviet Russia. The reason for this is that modern atheism is ultimately motivated by the logic of material production and human resources, that is by the needs of the developing economies and not an abstract ideology ${ }^{19}$.

The freedom from traditional and philosophical authorities as well as historical values inverts in modern atheism towards slavery to the scientifically articulated and verified. It is paradoxical, and fundamentally different from the Soviet model of atheism, that a slogan that "knowledge is power" is not appreciated in the economically advanced societies, for the allencompassing knowledge, that is knowing too much, is potentially socially dangerous. This entails in turn that knowledge and science both function in society in a reduced and popular form which does not allow one to judge of its certitude, quality and completeness. Scientific knowledge becomes a world-outlook, ideology and a filter of the social loyalty and adequacy. As a result the abuse of science becomes a norm which 
creates an illusion of its efficiency and truth in all spheres of life. The scientific method is treated as self-sufficient and not being in need of any justification and evaluation. Science proclaims the truth of the world from its own rationality which functions in the disincarnate collective consciousness. Supported through the system of grants from the economically powerful group, it is allegedly done for the sake of human good. However by functioning in society science forgets about that simple truth that science is the human creation and its initial meaning was to guard the interests of people and not to make them slaves and hostages of the scientific method.

The situation with the dominance of the scientific approach to all aspects of life becomes even more paradoxical when one realises that human beings do not become more happy and free from the aspects of material existence. They cannot escape social injustice, hardship of mundane life, diseases and moral losses. This happens because science as an ideology does not spell out what is most important, namely that it does not know the goals and ways of its future development. In its grandeur science has to intentionally disregard those aspects of reality which are not described by it or which behave sporadically and unpredictably with respect to scientific prognosis. Economic growth and welfare of the developed nations which used to live in comfortable conditions, the cult of consumption and greed demand more technological development related to the exploitation of the natural resources. Every new discovery in physics is employed for the optimisation of the production of goods and energy, so that one can speak about merciless exploitation of the physical reality in general. It is very seldom that the question of the legitimacy and justification of such an exploitation, or, as some say, "rape of nature" ${ }^{20}$ is even thought of. By making nature an object of manipulation scientific consciousness forgets of its humanitarian duties in respect to nature: nature must be "respected" simply because we live in it and that there is the light of that all-embracing reason (Logos) which we, human beings, carry in ourselves as little logoi. The objects of nature are inseparable from their creator, so that the oblivion of this fact leads to the loss of love of them in the same sense as the loss of love to other people. A careful insight of a philosopher or a theologian will unmistakenly identify the root of the problem, namely that the atomisation, and disassemblement of the physical reality in course of its exploitation has it origin in the ethical individualism of those who know this reality, that is the loss of love to nature in the scientific community. The individualism consists in that the exploration and acquisition of physical reality becomes an affair of that human spirit which is divided in its narrow professional and corporative interests in which the element of catholicity with nature through the divine-given existence, is forgotten because love does not rule anymore for the interest of knowledge and longing for the perpetual good.

The ambitions of the immanent secular reason, supported by the scientific achievements seem to be even more strange if one realises that modern science, in spite of its successes manifests the symptoms of a deep crisis related to the uncertainty of its goals. Scientific activity is purposive to the extent which accompanies any human activity. Any particular research has a concrete objective either to satisfy a practical interest or simply curiosity. However when we speak of the uncertainty of goals of science in general, we mean something different: scientific quest is spontaneous and is not related to the spiritual, infinite tasks of humanity. The practical purposiveness of scientific research thus unfolds only a particular sector of nature so that there remains a gap between that which has been known through a scientific phenomenalisation and that which cannot be known by science at all. 
This fact manifests that nature has a propensity to remain concealed and react with respect to human experiments unpredictably. As an example, one can point to nuclear physics which, by acquiring the mysteries of the microworld and risks creating a state of matter which can threaten human existence on this planet ${ }^{21}$. There is a danger in nuclear experiments of trespassing the boundary of the unconcealed, related to human existence, when constructed devices and artificial states of matter may behave in a nonhuman way, contradicting the initial objectives of experiments and turning science against humanity. A simple example from philosophical discussions of the 1950s is the atomic bomb which brought humanity to a new situation when the conditions of its existence are not controlled anymore only by the natural processes, but depend on the good will of people making decisions of using or not nuclear weapons, thus influencing global natural processes ${ }^{22}$. Another example is the ecological crisis. The melting polar cup of Greenland, extinction of some animal species and forthcoming migration of peoples living in the Arctic region show that technological applications of science escaping moral reason lead to the problem of the social and political order. Science through technology is not neutral anymore to economics and politics and, on the contrary, becomes their result and prophet. The process of exploration and knowledge of the surrounding world and thus its "transformation" becomes involved into the sphere of interests of the world's powers and classes so that its ethical significance is determined by its belonging to this or that social-economic demand. That which has been said entails that scientific knowledge and the very idea that society can and must develop only on the basis of scientific progress becomes an ideological dogma, the following and defending of which in turn becomes a matter of social loyalty. However, without understanding its logic and definite goals, scientific progress, being de facto unavoidable and irreversible, carries in itself a potential danger because of the unpredictable nature of it applications. Human beings want to live better and longer; however this natural desire does not supply a clear understanding of the goals of science, whereas humanity becomes more and more dependent on its achievements and applications.

The fact that scientific advance leaves huge realms of being unexplored and unknown becomes even more evident in theoretical sciences, in particular in cosmology. On the one hand cosmology provides us with a comprehensive theory of the universe supported by observations. On the other hand it has to admit that those forms of matter in the universe which are physically understood constitute only 4 percent of its material content (the remaining 96 percent associated with the so called dark mass and dark energy remain by now beyond the reach of experiments; their existence is a matter of theoretical conviction). The more cosmology refines its scenario of the universe's evolution, the more it realises the abyss of the physically unknown. Speaking philosophically, cosmology makes clearly seen the boundaries of the unconcealed which is related to humanity: it is only 4 percent of mater in the universe which can be said to be consubstantial to human physical and biological form. Amazingly, however, that in spite of all evidence for the limited nature of our knowledge of the universe, cosmologists sometimes position themselves as "prophets and priests" of the universe, preaching of it as if they know the absolute truth of the world. Such a conviction with respect to knowledge of the universe originates in a naïve representation of the universe as a whole as an "object" whose phenomenality can be exhausted through the logic of scientific signifiers.

One of the major attributes of modern science which makes it powerful is its radical 
mathematization of nature. Physics and cosmology, through mathematical models and theories, predicate realities inaccessible in direct experiments. There is a paradoxical shift of representations of reality here: unobservable intelligibleentities are treated as more fundamental and responsible for the contingent display of visible nature. As we argued elsewhere mathematization of nature is accompanied by the diminution of humanity, in particular the personal dimension of existence (see Nesteruk 2008, pp. 188-205). Person disappears from scientific discourse in spite of the fact that all articulated facts are made by persons. Science is being effected in the name of human persons, but this same person turns out to be outside of scientific description. Persons are needed for the anonymous objectives of science to disclose reality, but they do not exist for science as agencies of other non-scientific truths and individual lives. Science as a social process needs scientific workers but not persons as unique and unrepeatable events of disclosure of the universe. The same is true with respect to society which needs not persons but masses of individuals which are much easier adapted to the norms of materialistic thinking and behaviourist stereotypes based in the criteria of consumption of the results of technological progress. Modern atheism exploits this aspect of modern science by insisting on effective non-existence of personhood as a philosophical and theological notion. The oblivion of the person is treated by Christian theology as an encroachment on the absolute priority of the human world and those communal links in human societies which have formed the spirit of the Christian civilisation and integrity of its historical paths through communion with God. The oblivion of the person is the encroachment on the historical significance of its history impressed in the architectural image of European cities, masterpieces of art and literature, in the very way of European thinking and its values. The oblivion of the person constitutes an attack on all traditional forms of societies and life, which by the logic of the economical must cease to exist or become unobservable.

To defend the person and to reinstate it to its central status in the dialogue between theology and cosmology becomes a leading motive of the theological commitment. To reinstate the person means to understand that the problem of theology and science manifests the basic distinction and division of two attitudes to life in one and the same human person. The dialogue between theology and science becomes the explication the split between intentionalities which the human spirit attempts to reconcile. This, by using the language of Husserl, forms one of the infinite tasks of the human spirit to understand the meaning of existence. The very fact that this dialogue exists attests that human beings transcend the conditions of their physic-biological existence, the selfrealisation of a special place in the universe in which the function of the Divine image in man is realised (Berdyaev, 1944, p. 94). Thus, the fact of the dialogue attests also to that it contains the elements of transcendence and asymmetry between theology and science related to the human condition which is called personhood. It is this asymmetry, articulated in reflection, which we call the theological commitment, by confirming once again that this is an existential commitment. Correspondingly it seems doubtful that the dialogue between Christian theology and cosmology is possible without faith that both theology and cosmology represent modalities of the relationship between humanity and the Divine.

\section{Theological commitment}

\section{as a form of critique of secular science}

Contemporary science is historically rooted in the so called modernity (sometime historically associated with the fall of Constantinople in 1453) 
which has been responsible for dualisms such as the opposition between faith and reason, the dualisms which formed the grounds for excluding the divine and transcendent. It is modernity which is responsible for the claim that truth is based on universal reason, which tells us what reality is like. In this historical setting theology (as a way of life) was forced in the dialogue with science following the rules of modernity but not its own intrinsic logic of communion with God. These rules effectively dictated that theology entered the dialogue between faith and reason along the lines of adopted secular standards of scientific truth or normative rationality assuming a particular notion of the knowing subject (as impersonal and disembodied collective subjectivity) which is sharply opposed to the theological way of asserting truth through events of incarnate hypostatic lives. Seen theologically the secular standards of affirming truth are themselves based in certain myths and beliefs (for example in the existence of a universal human reason) so that they can affirm objective values only precariously. One of the dimensions of the modern dialogue between science and theology is exactly to put modernity's claim for the universality of truth under question (at least in what concerns the human sciences, including philosophy and theology), asserting that the modernity's ways of appropriation of truth were in a certain deviation from the unified vision of the world which was based in the characteristic alliance between faith and knowledge both originating in communion with God.

Modernity can be characterised as a change in the very way of questioning of God. According to the Christian biblical thinking the question never was formulated as "Whether I must believe in God?" and hence "Does God exist?" For a Christian the main question was a biblical one: "Who is that God whom I must trust?" There is a fundamental difference between belief in existence of God and trust to God. The God of the Bible requires from one much more than a recognition on the level of fact or theory of its existence. It demands from us "existential commitment" and entrusting our lives in God's care. This does not mean a lack of a rational element in such understanding of faith and trust. In early Christianity one can meet rational arguments in favour of the existence of God. It is enough to mention St. Athanasius of Alexandria, who pointed out that one can deduce the existence of God from observing the order and harmony in the world ${ }^{23}$. One must remember, however, that these arguments were aimed at Christians, that is to those who believed in God in order to reveal a rational element within Christian faith ${ }^{24}$. Rationality in faith aids one in elucidating the sense of this faith as faith in God, but not as belief in happiness and pleasures of life, for example. Correspondingly knowledge as such does not lead us immediately to knowledge of the Divine, for the Divine participation in us is not an object of direct "observation" or intuition, but is revealed only through a rational reflection ${ }^{25}$.

It is probably only starting from Descartes in the $17^{\text {th }}$ century that arguments on the existence of God become to be used in order to convince sceptics that God indeed exists. The intellectuals in Western Europe started to follow a view that religious beliefs are based, first of all, in rational convictions. This view corresponded to the rise of knowledge rooted in empirical justification and "scientific method." The arguments for the existence of God, beginning from the times of modernity, based on the logic of scientific demonstration, became the only legitimate foundation for faith in God at all. Divine revelation and personal experience were not considered anymore as a responsible judgement. The witness of the Scriptures was accepted only after the rationality of such an evidence was established through other independent methods. 
One can notice here how an increasing wave of secular thinking detached from faith began to impose its standards in the realm of faith. Secularism meant not simply that in arguments related to faith one must use reason, but that this reason is independent from faith and immanent to logic and laws of this world, being thus the only measure of all human activity, so that faith in God and religious experience acquired any sense only from within this reason.

By criticising faith for its unconvincing arguments and accusing it of being subjective and related to the overcoming of existential anxieties, "modernity" with its scientific method falls into another extreme: by assigning to reason disembodied universality, the discourse of humanity is thus being thrown away from the sphere of reason. Science becomes such a world-outlook which deals not with concrete human beings (with their immediate concerns, history and life), but as an indefinite and abstract, anonymous and non-empirical structure in being which "controls" every particular embodied creature. Nobody argues against the efficiency and importance of science in modern world, but it must be remembered that the adoption of the scientific method, in fact, manifests a certain belief in efficiency and existential importance of the anonymous and disincarnate way of knowledge in opposition to other forms of experience and views of the sense of the human. By decentring the cosmos, that is removing it from the sphere of the personal standing "in front of" (as an aesthetical category) and making it an extensional arena of blind physical forces (that is making it an object), human beings make a preference for a different mythology whose existential meaning is reduced to a simple desire to doom itself in the meaningless and contingent non-purposiveness in the universe, that is to be dissolved in the "cosmic homelessness". It is this decentring of the cosmos which is disclosed from within the theological commitment as based in a philosophical belief in the very possibility of such a decentring. Since this philosophical belief is not demonstrable from the ways of science itself, its very application remains no more than an empirical and contingent fact which points toward the contingent facticity of that worldpicture which is built upon it. Correspondingly all judgements of the scientific method on the possibility or impossibility of making inference on the trans-worldly foundation of the universe remain only precarious.

Modernity's stance on knowledge is seen as a certain deviation from the unified and spiritually universal approach to knowing reality which existed in late antiquity and Middle ages. Science or, more precisely knowledge (episteme), received its interpretation by theology which elucidated the sense of knowledge and the foundations of its contingent facticity. Knowledge understood by modernity excluded communion, that is the living participation and ontological relation with that which is being known (this relation, by using the language of Heidegger, one could interpret, on the one hand, as letting human essence be controlled by the circle of the unconcealed, and, on the other hand, for human beings to be able to remain concealed in relation to this circle, retaining its hypostatic, irreducible to nature qualities). Correspondingly the truth of such knowledge was limited to individual comprehension and to the correspondence of thought to its object (veritas est adaequatio rei et intellectus). Ratio, understood as a reduced and transformed version of logos of Greek Patristics, corresponded to the transition from the epistemic priority of communion to the priority of the individualised rational concept. The subject of logic and knowledge of modernity acquired a new qualitative feature of being able to wander at large over reality without being aware of its own fundamental otherness with respect to it, that otherness which, nevertheless, allows one 
to enter relation with reality and interpret it as words imbued with energy (logoi). The distortion of the sense of logos, understood as knowledge through communion lies in the foundation of all standards of thought which ultimately originated in Scholastics (and later in Descartes) and that was a considerable deviation from Christian theology of the late antiquity and Middle ages ${ }^{26}$. The change of view on knowledge as originating not in a hypostasis but in an individual was a certain distortion of anthropology in favour of psychological individualism and also the evaluation of a human subject on the basis of the juridical criteria $^{27}$. As a result, the understanding of objectivity, corresponding to this change, as being devoid of the living communion and based on the realities of the law-like order, led to the formation of the scientific and technical civilisation and methods of knowledge rooted in utilitarian principles related to the social rights and goals.

Whereas Western theology had to adapt to the demands of modernity and hence accept secular norms in its arguments on the presence of the Divine in the world and it interaction with the sciences, the theology of the Eastern Church retained "pre-modern" experience of seeing sciences and knowledge without adapting to the secularism of modernity. It is because of this that Christian theology, in particular in its Eastern Orthodox form, being faithful to the tradition of life in communion with God dogmatically and liturgically, thus transcending all historical divisions, feels empowered to question the foundational premises of modern science and the ways how its dialogue with theology is organised ${ }^{28}$. Since modernity is seen by the Eastern Orthodox as a certain deviation from the view that any knowledge contains a deposit of faith (let it be simple existential faith), Christian theology is given the right to use the language and critical methods developed within modern and postmodern philosophy, and other human sciences, in order to explicate those "faith-like commitments" which underlie modern science with its claims for truth and hence the imposed form of its dialogue with theology. If scientific claims for truth will be seen as endowed with the certainty of belief, the dialogue between theology and science will rise to a different level, namely that the distinction and difference between theology and science will be seen as the differentiation of intentionalities and constituents of one and the same human subjectivity. In this the dialogue between theology and science will acquire features of a phenomenological project where phenomenology is employed as a particular method in exercising a critical function of theological commitment. In different words, the discourse seen through the theological commitment cannot avoid phenomenology as a method of explication of this commitment.

The appearance of phenomenology in a theological discourse shows once again that theology in the mode of operation by reason is a form of critical thinking, because phenomenology is itself a mode of operation of critical thinking. The sphere of operation of theological critical thinking is in all realms where the Church (ecclesial humanity) meets historical and cultural reality. Theology creatively and critically thinks of any emerging historical problem or scientific theme, while remaining in the immutable state of the Church's spiritual life, because this life is experience of God, that is, of eternity ${ }^{29}$. Thus theology always functions from above mass-religious consciousness, as well as "secular" scientific consciousness which claims its freedom from any faith commitments; theology's unceasing task is to provide a constant and constructive critique of these modes of consciousness by referring them to the original divine image in humanity. 
In doing the above critique theology asserts itself as a meta-discourse, that is, as that form of critical thinking about different modalities of social activity, including a scientific one, which expresses the Divine presence and action, and which is not being bounded or exploited by some other particular human activities as their "prophetic" voice, be it the sociohistorical sciences or a kind of all-encompassing transcendental philosophy. The critical function of theology with respect to other discourses never allows theology to slip into such a position that its scope and place will be determined by other discourses, for example by the sciencereligion dialogue as such. In this sense theology can never be defined and positioned by secular reason and thus it does not accept the idea of a complete autonomy of that sphere of the worldly reality which is asserted through rational, that is scientific, understanding ${ }^{30}$.

One must take into account that by promoting theology to be a critical thinking we imply that this theology is in ecclesial setting, that is its inseparability from experience of God through historical tradition, liturgy and other forms of communion. This entails that by being critical with respect to various forms of thought theology represents the voice of the Church as that "place" in the universe where God meets humanity. This implies in turn that in order to remain critical and encompassing with respect to other discourses, the Church must remain independent in its voice and not to be easily adapted to the requirements of the secular reason, and, in particular, to the demands of the dialogue with science ${ }^{31}$. If this were not to be the case and secular reason uncritically claimed its right for neutrality, objectivity and independence from any faith commitments, faith and reason would remain parallel and non-intersecting in this age $^{32}$. But the separation of faith and reason is the consequence of many other divisions in one and the same subjectivity, and this separation in turn divides, in this subjectivity, the Divine and the created. It is this very division (Gr. diairesis), which St. Maximus the Confessor described as the moral tension between the Creator and the created, and whose alleviation is the ultimate goal of the human accomplishment of the Divine likeness ${ }^{33}$. If the tension between faith and reason is sought to be overcome, it is clear that it can be done only within a strong faith-commitment, and secular reason alone is incapable of attempting this mediation in a non-totalitarian and nonreductive way. However, if theology submits itself to the logic of the secular (for example, assuming a scientific form) it would become one particular, although very special, mode of activity separated from other modalities of human reality which do not fit in the rubrics of secular demands ${ }^{34}$. As an example, following the logic of the secular, theology has to deal with the issue of biological evolution and origin of humanity which, in the perspective of science, accentuates the physical and biological, that is corporeal and hence collective. But no theory of evolution can literally say anything about the origin of hypostatic human subjectivity, that is of persons who articulate this same evolution as such. It is persons who have empathy and love, who can rejoice and suffer, but whose account is impossible in science. Theology, in contradistinction with science, is an existential enterprise never abstracting from the concreteness of the human person and its desire to attain immortality. Theology as experience of communion with the invisible origin of all is life, so that it encompasses all reality in which humanity is present not only physically (through the senses and discursive cognitive faculties), but through insight (Kant would say judgement); thus it is intrinsically present in all disclosures and manifestations of reality by human beings, so that all reality's articulations are referred to and judged by the theological modality of life. 
The theological commitment in the dialogue with science means the radical stance on science following from the objective requirement that ecclesial theology must draw a clear borderline between the dispassionate contemplation of what happens in modern science and its involvement in $\mathrm{it}^{35}$. The criteria of delimiters can be set in words of Jesus Christ: "What does anyone gain by winning the whole world at the cost of destroying himself?"(Lk. 9:25; Cf. Matt. 16:26). In modern terms it would sound like this: "What does humankind gain by exploring and subjecting the world to its curiosity and utilitarian needs at the cost of loosing the sense of integrity of existence and the vision of humanity's infinite tasks and spiritual goals as linked to the transcendent?" Theology must not, it has no right to be involved in those movements of a new nihilistic spirit originating, in fact, from the modern apology for atheism which dare address to modern men the questions like this: What is the point of the humanity of humans, the naturalness of nature, the justice of the polis, and the truth of knowledge? Why not rather their opposites, the dehumanization of humans to improve humanity, the systematic raping of nature to develop the economy, injustice to keep society more efficient, the vast ocean of distracting and existentially irrelevant information to escape the commitment to truth? Since these counter-possibilities are no longer just a hypothetical speculation but nearly the sole program of the ideologies that have dominated in history since the beginning of the $20^{\text {th }}$ century, the Church and all those for whom the humanity of humans, the naturalness of nature, the justice of the polis, and the truth of knowledge remain absolute values, must have a decisive and radical response to it by conducting the systematic critique of those forms of secular (and scientifically based) thinking which encourages mass-consciousness to the "winning" the autonomous scientific part of the world at the cost of destroying communion with the whole. However, its theological radical critique of the scientifically asserted world does not preclude this same theology from being radically positive with respect to science and the world. What Orthodox theology judges is the alleged autonomy and independence of the scientific view of the world from the very intricate inherence in the human and hence in the Divine (c.f. Nellas, 1997, pp. 93-104). The positive judgement of science and the world originates from the sanctification which existential ecclesial theology undertakes by bringing all fruits of human labour, including science and its picture of the world, to the their correct operation in the wholeness of communion.

Here not only a dispassionate critique of a scientific secular mode of thinking is implied. The Christian imperative calls into question the ethical value of the pure secular science with its pretence to objectivity and neutrality and its claim for the truth of being, as if it is devoid of any faith assumptions and possibility of transcendence. It calls into question some gnostic ambitions of modern science to be the power which helps people to solve problems of physical survival. In these pretensions modern science denies not only theology's right to predicate reality, but it denies also philosophy (as love of wisdom) for the uncertainty of its judgements (certitudes négatives). The scientific secular mind aspires not to philosophy, but to gnosis, that is, precise and demonstrable knowledge. Its aim is to justify the thesis that one must keep silent about that which cannot be spoken in terms of the rubrics of reason. Theological commitment advocates the opposite in a sophisticated, apophatic, sense: one has no right to keep silent about things of which we cannot speak (using pure reason), for in this case we pass over in silence the essence of our existence. Yet one can talk about ultimate existential things only through metaphors and aberrations in being clear that the fullness of 
essential questions cannot be exhausted by the faculties of reason. When the precision of judgement becomes an absolute value so that all questions beyond this "precise gnosis" are abandoned, human being feels lost and deprived of its own existential anxieties. In this sense faith implied in the theological commitment never threatens science and philosophy: on the contrary it protects them from the all-pervasive pretensions of gnosis (and, as a result, from atheism and soulcorroding nihilism) (c.f. Ratzinger 1993, s. 40). Theology based in faith, being all inclusive, needs both philosophy and science because faith operates in the conditions of the incarnate humanity which seeks and asks for truth. Faith has its duty with respect to reason ${ }^{36}$ but it still remains critical with respect to both philosophy and science.

There must be, however, made a comment on the sense of our usage of the word "critique" if it applied by theology with respect to secular thinking, including science. In fact, there must be made a distinction between our sense of "critique" and atheistic criticism of theology based on the grounds of the so called "critical rationalism". Briefly, the essence of this philosophical trend descending from K. Popper, and being first of all represented by H. Albert ${ }^{37}$, consists in appeal to constant understanding and revaluation of the achieved landmarks of knowledge, revising and amending all empirical results as well as intellectual constructs. This strategy of research and seeking for truth is treated as to be genuinely rational. Correspondingly the attitude of the atheistically oriented representatives of this "critical rationalism" is to criticise religion, and Christianity in particular, for being dogmatic and using the "strategy of immunisation" from any criticism with respect to basic dogmas of faith. This concerns first of all of the central theological conviction of existence of God. Since no rational demonstration of such an existence is possible, so that any possible statements about God can be doubted and hence criticised, theology immunizes this aspect of faith from any rational critique and thus it falls into the fallacy of dogmatism, that is an arbitrary chosen premise for any further deductions. In view of these accusations, our main concern here is the following: if the followers of "critical rationalism" charge religion and theology with dogmatism and irrationalism, how can theology, according to our view, be a universal tool for criticising secular thinking and science? How it is possible that behind the alleged irrationality of theology there is something which makes it "rational" in the sense of being able to oversee and justify all discourse based on the rationality of reason. In other words, could theology respond to "critical rationalism" through its critique? The answer to this question is already present in history of thought and it further explication could form a separate research on science and religion ${ }^{38}$. Here we would just like to provide a very brief response, related to our claim that theology is destined to exercise critique of secular thinking.

Any philosophical strategy with respect to science, including that of "critical rationalism" leaves one basic question unanswered despite a continuing criticism and revision of scientific views of the world. This question is about the very facticity, that is the very possibility of scientific advance which allegedly goes along the lines of "critical rationality". As we mentioned above this advance and "critical rationality", acting upon it, does not understand its sense and its goal. Its telos, if it is somehow envisaged, must, from the point of view of critical rationalists be corrigible and amendable, that is contingent and historically adjustable. But such a critical approach to the ways of human knowledge as part of life leaves humanity with the state of despair, cosmic homelessness and non-attunement to the universe which have been mentioned before. Theology in 
this sense provides human search for truth with teleology in the sense of orientation, recourse to what is solidly exist and to the sense of what human life is about in the perspective of eternity. It breathes a meaning into the disenchanted world so that human beings no longer suffer from being mere spectators staring at the universe's emptiness. A critical function of theology is to override any form of mundane criticism based on scientific rationality and to extract out of this criticism an ultimate positive core of the human existence in the perspective of the promise of salvation. To overcome the critique of theology from the side of critical realists, this theology must establish critique of the critique. Thus it must transcend in the name of restoring the home place for humanity. Theology and theologians cannot permit anyone to prevent them from advocating and defending the humanity of the humans, naturalness of nature, justice of the police. Any cosmological theory with its advance of corrigible findings and mind-boggling discoveries must be subjected to an existential and hence theological critique: the divine image of humanity must be preserved even if this cosmology "crushes man under the weight of the astronomical facts."

\section{Theological commitment in a phenomenological modality: the centrality of person}

In its intrinsic critical function upon all social undertakings theology manifests itself in a phenomenological modality, that modality which studies, analyses and qualifies states of human consciousness by referring them to their ultimate source in persons who inhere their image in the Divine. Theology deals with phenomena, in human consciousness, of the presence of God, so that in this sense theology is the domain of phenomenology. However unlike classical philosophical phenomenology which fights against transcendence, ecclesial theology assumes the possibility of transcendence in its stance on humanity which, belonging to this world and articulating it, does not allow this world to swallow and reduce humanity to nothing. Here transcendence means the ability of human persons to preserve their otherness with respect to the universe even when this universe is effectively humanised through human articulation. However this otherness, understood theologically, if it is realised and preserved, and if it is developed and extended through the articulation of the universe, contributes to the growth of religious faith. Thus theological commitment in cosmology, as the movement "beyond secular reason", implies, through bringing personhood to its God-given centrality in being, the deepening and acquiring new experience of God which is manifested in new forms of thought and philosophical language. If cosmology considers itself as self-generating knowledge in which God-given centrality of humanity is lost or distorted, human thinking of the universe and of its own position in it becomes imbued with the existentially irrational, the sense of homelessness, not being attuned with and incommensurable to the universe, leading to what Marcel described as the "crushing of man under the weight of astronomical facts", that is to death which strips all sense and value of human life. Seen in this perspective any cosmology, if it looses commitment to existential faith (not mentioning at all its Christian sense), that is, if it does not promote human life on this planet, can become a spiritually damaging practice, where the boundary between the human and inhuman in the universe can be trespassed and the sense of life is lost. All this means that the explication of theological commitment in cosmology implies the work of the spiritually enlightened reason with the aim to explicate persons and their communal affinity to the Divine.

By using phenomenology as a methodological tool in explicating theological commitment we 
assume its extension beyond its "classical" sphere associated with Husserl and his followers ${ }^{39}$. From a philosophical point of view the extension of phenomenology towards theology (a so called "theological turn") is not unproblematic (Janicaud 1990) since it deviates from the initial objectives of phenomenology which was fighting against transcendence and made a methodological doubt of God through a phenomenological reduction (Husserl 1998, § 58). The question is: do phenomena associated with the presence of the Divine retain in them something which does not exhaust them and does not allow their complete acquisition by consciousness? ${ }^{40}$ Such phenomena change the classical philosophical stance on the a-priori character of the cognitive faculties and the ability to constitute phenomena as phenomena of consciousness. Theology benefits from such a philosophical discussion because theology, having had duties with respect to reason, can be theoretically advanced for the dialogue with science to become more articulated in modern philosophical, linguistic and semantic formulae. This, in a way, constitutes a patristic ideal; correspondingly being in the same tradition contemporary theology should learn from the early theologians how to conduct a dialogue with science and philosophy by employing contemporary philosophical thought. In reference to the practices of the Fathers this constitutes a neo-patristic dimension of the dialogue of theology with science ${ }^{41}$ as another dimension of theological commitment. Correspondingly the explication of the theological commitment in cosmology becomes a contribution to this synthesis as the extension of old forms of thought and existential meanings towards our age.

The theological commitment in cosmology implies a certain stance on anthropology, or personhood. It sees the split between faith and reason, or the split of intentionalities in one and the same human subjectivity, as the loss of centrality of human person in the dialogue. Correspondingly it is because of the advance of technology and science, which diminishes a personal dimension of existence, there is a growing concern about the respect of human dignity and freedom in our time. Humanity, understood theologically as events of hypostatic existence, manifests the living transcendence (through communion) and thus the possibility of reaching out to the transcendent, as that personal rationality through communion with which the world receives its meaning as the means of the dialogue between humanity and God. The dialogue between Christian theology and science becomes a radical form of the intellectual, cultural and spiritual mediation among all splits and disintegrations in human life. It demonstrates that there is a common ground for all humanity in otherness of God, as well as in consubstantiality with the universe. This position confirms an old patristic view that theology is a mode of life and the essence of the human condition is communion with the divine. Within this perspective the dialogue between theology and science rejects either the dominance of pure faith or pure reason, for it considers both of them within the integrity of hypostatic humanity as two modes of participation in the divine. ${ }^{42}$ At the same time it does not want to consider theology as a dialect enclosed in itself and unrelated to other spheres of human reason, although it never adapts to any unquestioned norms of the secular reason ${ }^{43}$.

In a phenomenological perspective the problem of mediation between theology and science can be formulated as the reconciliation of the two types of experience in one and the same human subjectivity. On the one hand, in science, this experience is empirical and theoretical, delivering to human subjectivity knowledge of things "present in their presence". This is achieved by the fact that all phenomena related to the outside world are constituted within the 
immanence of the ego. Regardless as to whether one means empirical observations and controllable measurements, or mathematical statements, what is evident is that in all these cases the "reality of the outer world" is affirmed through the structures of the constituting subjectivity. On the one hand consciousness poses scientific phenomena outside itself making them objects, as if they exist separately and independently of the subject; on the other hand the form of the content of these phenomena is generated by the human subjectivity so that the form of these phenomena is immanent to human consciousness. Thus, the transcending tendencies in scientific knowledge are present in the very foundation of its natural attitude, whereas phenomenology attempts to clarify the sense of this transcendence by referring the to the subjective pole of knowledge. Scientific phenomena, articulated as certain transcendences of the sphere of subjectivity, can be represented discursively as objects that manifest themselves as being poor in terms of their intuitive content, that content which forms an invisible and silent context of that objective reality which appears through the procedures of science. In other words, by making phenomena objective in a scientific sense, what is left behind is the intuitive content of the life of consciousness which cannot be phenomenalised at all; thus human subjectivity cannot be reduced to that which is phenomenalised; hence there is something in this subjectivity - its personal, hypostatic centre - which passes over any scientific presentation of life. Thus, human persons transcend the scientifically organised universe in a very sophisticated sense: even if cosmology asserts human existence as insignificant, it cannot remove the intuitive content of the transworldly dimension which pertains to human persons as divine-made agencies. Thus, when the scientific mind poses physical reality as objective and independent of human insight, it is not as if human history has been "cosmosized", that is placed in the cosmic context, being reduced to the necessities of substances and the laws of the universe. It is completely opposite: the universe is being humanized, becoming the content and structure of the human subjectivity as part of the unfolding human history. The universe becomes immanent to humanity whereas humanity retains its transcendence to it. In spite of the fact that this transcendence is always in place and is the motivating force of any scientific enquiry, which never stops because science never abolishes the freedom of humanity to progress beyond the already achieved, it is this very science which cannot give an account for the ground of this transcendence because it does not account for persons. The dissatisfaction of science by its inability to account for the contingent facticity of personhood leads, in a paradoxical way, to its fight against transcendence as the retaining of those foundational intuitive existential contexts which make possible any scientific articulation.

Theology exhibits a clear difference with science: it claims that it is possible to accept the phenomenaof thedivineasabsolute, unconditioned by thought or speech, that is to retain as "present in absence" that which is beyond the expression of what is given or revealed, that is beyond of that which can be phenomenalised. On the one hand, the phenomena of the divine are immanent because they belong to human experience, on the other hand they are transcendent because they cannot be phenomenalised within the rubrics of pure thought and language because of its inability to exhaust by means of signifiers that which it is supposed to signify. One can say that theology retains transcendence in immanence. Here classical phenomenology, with its philosophical respect for immanence, enters an irresolvable conflict with theology. According to classical phenomenology the phenomenality of God, as well as the underlying facticity of science, would be forbidden, insofar as they re-establish 
transcendence as opposed to the reduction which attempts to neutralise it. Science is not subjected to this problem to the same extent because the scientific discourse does not attempt to see the "other" side of physical phenomena, that side which is responsible for their contingent facticity. In science human subjectivity operates in the natural attitude by affirming objects of the universe as existing outside and independently of this subjectivity. However, the facticity of that givenness of objects of physics, that is their articulated phenomenality, lies in that same subjectivity which attempts to be abstracted from them. If in theology the problem of the phenomenalisation of the divine coincides with the problem of theology's facticity, in science the obvious phenomenalisation of the finite things and events does not naturally bring human subjectivity to an enquiry about the facticity of science which explicates these phenomena. Science can effectively function within the sphere of immanence of that subjectivity which generates it, remaining merely an efficient tool, the very possibility of which remains obscure (Gurwitsch, 1966, pp. 399-400).

Then a reasonable question arises with respect to the dialogue between theology and science: what is really meant by the dialogue between theology, which implies transcendence in its very definition, and science, whose monism, as immanentism, is implanted in scientific methodology so that transcendence is precluded? The situation is aggravated by the fact that transcendence is not self-evident even in theology if it is taken in a purely philosophical mode. That philosophical theology which considers God in terms of existence and real transcendence, causality and substance, is subject to a phenomenological critique: God is disqualified from being a phenomenon. In contradistinction to this, the theology of experience is based on facts and manifestations linked to the Scriptures and Eucharistic communion and here we deal with such phenomena which render a sort of concealment, not being fully disclosed through those aspects of intuition which cascade towards expression. In other words, theology understood as experience deals with phenomena which are pre-theoretical. Hence there is a general problem of how to express theoretically, pre-theoretical experience; for example, how to employ thought and speech in order to express that which, by intuition, cannot be thought and spoken of, that is, that which exceeds the limits of the constituting ego. In other words, how is it possible to retain the transcendence of God while speaking and thinking of him within the immanence of human subjectivity? Evidently, a similar question must be formulated with respect to the universe: how to retain the transcendence of the universe as a whole while speaking and thinking of its observable and non-observable parts within the immanent subjectivity.

The Greek patristic response to such questions would be that knowledge of God cannot be exhausted by reason and its linguistic means; theology operates with metaphors and allegories which, however, reflect existential, precategorical and pretheoretical truth. The challenge to philosophical theology, which appropriates existential truth of God within the limits of reason, is to overcome the phenomenalisation of the transcendent and thus to preserve transcendence in immanence. In different words, theology has to deal with the intrinsic ambivalence of the givenness of the divine, that is, with its "presence but in absence". If theology, being scrutinised by philosophical thought, is in need of justification of its own ability to retain transcendence within the sphere of phenomenality of consciousness, cosmology, if it intends to engage with religion, needs a similar sort of justification but to a much wider extent. This implies that the problem of mediation between theology and cosmology 
requires one to deal with a generic issue of the possibility of transcendence in cosmology. In more specific words: in what sense does intrinsic immanence of scientific assertions about reality retain in itself the elements of transcendence; or how the theoretical speech of scientific discourse retains the signs of that otherworldly ground of the overall facticity, which is fundamentally pretheoretical. One must not be surprised that this question is formulated by persons. In other words the retaining of transcendence means here the transcendence of persons as not reduced to that which is phenomenalised by the sciences. Seen in this way the difference between science (cosmology) and theology can be described in terms of the difference in expressing experience of transcendence.

The explication of this last mentioned difference and the outline of the ways of reintegration of intentionalities employed in science and theology can be made on the level of those border-line situations where the excess of intuition of a phenomenon effectively blocks its discursive exhaustion and renders in it something which has not been intended and conditioned by experience. Here cosmology provides us with at least two issues relevant to our concern: cosmology of the origination of the universe as a single and unrepeatable event, and the issue of position of humanity in the universe in the perspective of an unrepeatable and incommunicable event of embodiment (incarnation) of every human person. The universe appears to humanity as given in its contingent facticity, but its sense and origin are not comprehended by humanity. Humanity, on the contrary, is comprehended on the basis of the event of communion with the universe in the very measure that this event is not comprehended. Similarly the event of birth as contingent hypostatic incarnation (the event of hypostasis in Levinas' terminology (Levinas, 1987, pp. 42-43), is not comprehended by the personal subjectivity (this event does not show itself to subjectivity) but this person is comprehended on the basis of this event in the very measure that the person itself does not comprehend the event. ${ }^{44}$ It is the inability to comprehend the sense of embodiment in its hypostatic facticity that makes the problem of origin of the universe as well as the problem of origin of the personal existence one and the same unsolvable metaphysical mystery (c.f. Marcel, 1965, p. 24). Correspondingly, one can speak about incommensurability of the universe as well as the facticity of personal existence to all forms of conceptual thinking. It is the inability to comprehend the pre-theoretical and pre-conceptual in the givenness of the universe to human person as well as the givenness of the person to itself, that indicates that the universe and person show themselves in rubrics of immanent consciousness while remaining incomprehensible and retaining inexhaustibility in terms of conceptual thinking.

\section{Concluding remarks}

The existential and phenomenological explication of the theological commitment in modern cosmology as the unfolding of the sense of the universe from within communion events entails that cosmology, in a way, turns out to be "subordinated" to anthropology. Philosophically this means that the interpretation of cosmological ideas is based on the epistemological centrality of humanity as such a kind of being from within which that which is called "the universe" is disclosed and constituted. Theologically, this means that the sense of the universe is established from within the relations between God and man, that is from within a concrete earthly history being an arena for these relations. As was expressed by C. Yannaras, if "the entire fact of the world to be constituted as an existential fact, then every reality is recapitulated in the relationship of humanity with an active reason (logos) as an invitation-to-relationship, which is directed 
towards humanity alone" (Yannaras, 2004, p. 137). In both philosophical and theological aspects of such an approach to the universe one can find a phenomenological reversal of the anthropological problem: humanity is not inserted in the allegedly pre-existing cosmic history but, on the contrary, cosmological evolution has its origin in the history of the human as that primary and inherent existential beginning of any possible articulation of the world. This beginning expresses that which G. Marcel called the initial and unresolvable mystery of the human existence (Marcel, 1965, p. 24). It is that mystery which is associated with the fact of humanity's creaturehood, its mystical coming into being through the act of the Divine love. It is the stance on the spiritual centrality of humanity in the universe and the presence of the Divine image in articulations of the universe which constitutes the essence of the theological commitment in studying the universe. A phenomenological method of treating the content of cosmological theories as the content of human experience, so to speak, their interiorisation by the ego, explicates a simple eidetic truth that cosmology manifests the spiritual condition of humanity, that condition which is subjected to a trial of free thinking of the universe. Physical cosmology mercilessly dooms human beings to homelessness in the universe, their mediocrity and effective non-existence in the divided, and sometimes non-consubstantial layers of physical reality. By so doing it subjects the human spirit to a severe test of resisting despair and oblivion and encourages transcendence, that is the sense of its commensurability with the eternal as the God-given ability to contemplate all temporal and spatial extensions (diastema) as having origin in the same otherness of their creation which consciousness has.

If one places such a vision of the universe in a cosmographic context, the resulting "spiritual cosmology" turns out to be geocentric, because it is anthropocentric. However this egocentricity has a theological foundation, for the meeting of God with humanity took place on Earth and it is in this event through which the basic divisions in creation have been archetypically overcome and brought to the unity. Then that geocentrism which pertains to the fact that the universe is disclosed from a specific and contingent location in the universe becomes an expression of the Christocentric essence of cosmology, for the very possibility of the integral knowledge of the physically disjoint world has its origin in the archetype of the Divine image in man, that is of Christ, understood not only as a carrier of the human nature, but also as the Logos-Word of God who did not cease to be at the right hand side of the Father and who continuously sustains creation and its economy at all scales and all remote corners of the universe. It is this archetype, when Christ is treated as the Lord of the world ( $\operatorname{Rev} 1: 16$ ), which is gifted to humanity in order it could know the universe at the scales which incommensurably exceed in depth as well as at large the physical and biological parameters of the human existence. One can say that the very possibility of knowing the universe becomes in a certain way the experiencing of the event of the Incarnation of the Lord of the worlds from within which the universe manifests itself as an event of the human history.

If, for a moment, one disregards a theological stance on the human existence and approaches it on the grounds of the physical and biological, as well as cognitive facticity, including the faculty of the rational comprehension of the world, the universe will appear to us from within the transcendental delimiters which pertain to the human condition. The universe is constituted from within these delimiters so that the picture of the universe comprises not only that which can be phenomenalised, that is represented as objects, 
but the very conditions of the possibility of such a constitution. The possibility of elucidating these conditions in the strict discourse of the natural sciences seems to be doubtful. If one assumes that the cognitive faculties as well as human reason have foundation in something physical and biological, one looses here the problem of hypostatic, that is personal existence, for personhood is that aspect of the individually unrepeatable, isomorphic to the world existence with respect to which science can only think in terms of riddles. It is because of this that theology enters a cosmological discourse as a pointer to that from which the transcendental delimiters in the constitution of the universe can originate, namely to the Divine image in man. In this sense the explication of those epistemic procedures which are employed in cosmology, in its essence, will be the explication of content of the idea of the divine image in man, or, to be more precise, of that impetus which is still acting in humanity's postlapserian condition and which attempts to restore the distorted image. Correspondingly, the method of such an explication, based in transcendental philosophy and phenomenology, becomes intrinsically manifesting that theological commitment which implicitly present in cosmology. Our desire to reflect upon knowledge of the universe from within experience of life corresponds to that endeavour of the modern philosophy of religion which overcomes that which Heidegger named "ontotheology". In view of the objectives and tasks of the present research this would mean the overcoming of "ontocosmology" as that abstract science of the universe as a whole which, ultimately, in analogy with ontotheology must lead to the "death of the universe", certainly not in a physical, but moral sense, as that kind of being which is devoid of the value and beauty by which the cosmos of ancient Greeks was filled in.

\footnotetext{
Jean Ladrière expressed a thought that in order to explicate the analogy between the deep structure of nature and the structure of human existence as openness, creativity, possibility etc., one needs to enter what he called the "domain of the word" which, in our parlance, would correspond to thought within the "theological commitment": "The problematic of nature can thus be linked with the problematic of human existence. Still there is no continuity between these two domains. There are perhaps indications pointing in a certain direction but it is not within the power of cosmological thought, even when developed, to become a consideration of finality, to enter the domain of the word. Only by meditation on what properly belongs to the word can one open another way of understanding (if one exists), leading towards...faith" (Ladrière 1972, p. 186).

2 This is a different way of expressing that which Gabriel Marcel asserted in 1940 in his book Du Refus a l'Invocation (Marcel 1940), when he discussed a paradox related to the representation of the universe as an object: "The more I insist on the objectivity of things, thus cutting off the umbilical cord which binds them to my existence, that one which I call my organo-physical presence to myself, the more I affirm the independence of the world from me, its radical indifference to my destiny, my goals; the more the world thus proclaimed as the only real one, is converted into an illusory spectacle, a great documentary film offered for my curiosity, but which is ultimately abolished because of a simple fact that it ignores me. I mean that the universe tends to be annihilated in the measure that it overwhelms me. And this, I believe, is that which is forgotten whenever one attempts to crush man under the weight of astronomical facts" (p. 32). N. Berdyaev also was worried about the dominating power of nature upon human beings by calling it "slavery to nature". To relieve oneself from this slavery one must exercise an "active resistance to those impersonal forces of the world which desires to tear in pieces and enslave it" (Berdyaev 1944, p. 49)(translation corrected).

3 Positive certitude is typical for the sciences dealing with knowledge of objects can be described as that science operates with some precarious and incomplete data about these objects which are amended and corrected in the course of science's progress. The paradox of science is exactly in that this uncertainty, corrigibility of its results is the condition for science to function at all. Another aspect of science is that it cannot know things in the context of the wholeness of the world. By contrast in philosophy, in what concerns its perennial questions about the world as a whole, there is no visible progress, so that it is able to speculate about the world only in rubrics of what is called by Jean-Luc Marion negative certitudes. (See details of this concept in (Marion 2010).

4 C.f. (Torrance 2001, p. 2). See also (Clément 1976, pp. 102-3).

5 One can point to Husserl, who in his Ideas I (\$ 58) subjected God to reduction, bracketing it and depriving it of any transconscious status (Husserl 1998).

6 For a systematic approach to such phenomena see (Marion 2002). See my paper (Nesteruk 2014) where the idea of saturated phenomena is applied to the universe.
} 
7 Our usage of the adjective "existential" must be carefully distinguished from the same adjective which is sometimes used by cosmologists in the context of the stated smallness and insignificance of humanity in the universe; see, for example, (Primack, Abrams, 2006, pp. 273-78).

8 C.f. (Primack, Abrams 2006, p. 282), (Ladrière 1972, p.150).

9 See, for example, (Krauss 2012, pp. 118-19).

10 It is worth recalling Kierkegaard expressed in a dramatic form his anxiety about the impossibility to describe one's position in being: "One sticks his finger in the ground in order to judge where one is. I stick my finger in existence - it feels like nothing. Where am I? What is the 'world'? What does this word mean? Who has duped me into the whole thing, and now leaves me standing there? Who am I? How did I come into the world; why was I not asked, why was I not informed of the rules and regulations... How did I come to be involved in this great enterprise called actuality? Why should I be involved in it? Am I not free to decide? Am I to be forced to be part of it? Where is the manager, I would like to make a complaint!" (Kierkegaard 2009, p. 60).

11 As was suggested elsewhere the universe as its past, even if human beings know their meaning only precariously, can be respected, as certain ancestors of our being, so that this respect can establish a sense of communion with the universe which overcomes loneliness and despair (Primack, Abrams 2006, p. 291).

12 (Pascal 1962, p. 199 (c.f. p. 113)) [English translation: (Pascal 1959, p. 78 (c.f. p. 39)].

13 Humanity, first of all, is not satisfied by that vision of its own place in the universe which positions it in the same way as "marble is in the bag" or a "cat is in the house", or "a teacher is in the classroom"; "... it is at this point that a kind of rebellion takes place: the full reality of the individual is surely not exhausted by statistics, and the identity of the person demands and appreciation of his situation in the world distinct from one's situation in the world." (Natanson, 1959, p. 233).

14 The literature on this topic is vast. See a concise and eloquent review of recent discussions in (Halvorson, Kragh 2012).

15 See a more elaborate formulation of a mysticism of immanence, for example, in (Comte-Sponville 2006, pp. 145-212).

16 As was argued by G. Goutner, the alleged ideal of humanity, understood, for example as it unity, simply does not exist. One can think of it only in a modality of hope which has a religious nature (Goutner 2013).

17 See examples of this in, for example, (Dawkins 2007), and (Stenger 2008).

18 See, for example (Comte-Sponville 2006).

19 This point was emphatically defended by C. Yannaras in his article "The Church in Post-Communist Europe", (Yannaras 2011).

20 This was the title of Ph. Sherrard's book The Rape of Man and Nature: An Enquiry into the Origins and Consequences of Modern Science (Sherrard 1991), where he aggressively criticised modern science for the exaggeration of the sphere of applicability of its methods and resulting dehumanisation of humanity and desanctification of nature.

21 For futurological accounts based on the threats originating in modern science see books of (Leslie 1996), and (Rees 2003).

22 N. A. Berdyaev prophetically argued in the 1930s that humanity enters a new era when the stability of the world will depend on moral decisions of humanity of how to use technology available through scientific advance. See his paper (Berdyaev 1991).

23 Athanasius of Alexandria, Contra gentes, 35:4 [ET: Nicene and Post Nicene Fathers, series 2, vol. 4].

24 Clement of Alexandria, The Stromatata, or Miscellanies, Book I, Ch. 5 [ET: Ante Nicene Fathers, vol. 2].

25 The importance of the rational faith, as the faith reflected and elucidated by reason, was accentuated by Thomas Aquinas (Summa Theologia, 1a,2,1) in his polemics with St. John of Damascus (Orthodox Faith, 1,3), according to whom faith in God is an innate quality. (See discussion of this issue in (Coplestone 1950, pp. 336-37.)

26 The problem of changing views on the role of subject and the sense of knowledge in history of philosophy (regardless to the Christian context) was carefully traced by Heidegger in his book on Nietzsche (Heidegger, 1997). Contraposing modernity to medieval scholastics (which he links to knowledge "associated with the order of salvation"), Heidegger points out that "man, independently and by his own effort, contrives to become certain and sure of his human being in the midst of beings as a whole" (p. 89). According to Heidegger, the major task is search for the ways of such assurance, a method, which inevitably lead to the Cartesian formulation "Cogito ergo sum". However, the proclamation of this thesis does not liberate the theologically committed ego from asking a question about the foundation of the very contingent facticity of cogito. This, as the Fathers of the Church asserted was not a question of knowledge as such, but the question about the logos of this knowledge.

27 Nowadays such a distortion of anthropology leads to the formation and cultivation of a type of person whose ability to function in the conditions of dynamical communion is in a state of decline. This concerns first of all with the limited freedom of speech, independent thinking and judgement, in the conditions when the ability to imagination and even more, volition, are essentially supressed.

28 This is a particular dimension of a possible response to the question posed by A. Walker more than twenty years ago: "Given that modernism by definition wants to scrutinise and criticise all traditional ways of thinking and expression-and modernism is no respect of confessions, for all historic and traditional commitments are grist to its critical mill - is there any way we can critically evaluate modernist thought from the perspective of historic Christianity?" (Walker 1988, p. 4).

29 In words of D. Staniloae: "The very existence of the Church is an effect, continually renewed of the action of the Holy Spirit in creating communion" (Staniloae 1980, p. 218) "The door of the infinite riches of the personal or interpersonal divine being has opened up before the reflections of Orthodox theology, and with it the prospects of an endless progress of the human spirit within the divine" (Ibid.) "The paradox of the Church mission in "this world" is just in that the power of the ecclesial influence of the world directly depends on the ability of the Church to be "bigger than the word", to transcend the world and to see it through the "Divine vision"”. (Filaret 2004, p. 53).

30 As it is emphatically advocated by J. L. Marion, theology deals with the saturated phenomena, whose phenomenality cannot be embraced by means of scientific analysis. 
31 This makes Christian theology flexible to any scientific developments without being assimilated by them. According to V. Lossky, Christian theology "..is able to accommodate itself very easily to any scientific theory of the universe, provided that this does not attempt to go beyond its own boundaries and begins impertinently to deny things which are outside its own field of vision" (Lossky 1957, p. 106). This accommodation means to remain critical to all scientific claims for monopoly of truth, that is to remain "meta-discourse".

32 This thought was discussed by J. Shakhovskoi in the context of the views of the physicist Max Planck on science and religion. Planck (Planck 1938)) compared the growth of scientific knowledge and of religious experience with two parallel lines. They have a common point of intersection, infinitely distant from ourselves, that is, distant from the present age and being in the age to come (Shakhovskoi 2003, p. 15).

33 See in this respect: (Thunberg 1995), (Larchet 1996).

34 Such a "secular" theology, for example, would not be able to take into account liturgical rites, communities and communion as an indispensable component of experience of the Divine.

35 In a general context this implies the possibility of the critical evaluation of modernist thought from the perspective of historic Christianity.

36 One implies here the duty of faith with respect to philosophy. Christian teaching on the Incarnation, in order to reveal God in its humanity, appeals to a new and superior reason which pertains to human reason. Christians do not have choice in possessing the "kind of reason", that is logos, because they bear name of That one Who is the Logos Himself. This is the reason why Christians had to acquire the achievements of Greek philosophy and sciences (one may recall Clement of Alexandria who argued in favour if this). St. Augustine asserted that Christianity cannot be compared with ancient religions (theologia civilis and theologia fabulosa- political theology and mythological theology), with the only exception theologia naturalis (natural theology), that is with an attempt of rational knowledge of God through studying celestial movements. Augustine insists that the term theologia, for Christian faith, must be understood only as true knowledge of the Divine. Since the notion of truth is employed, "...comparison must be made with philosophy"; thus faith becomes, first of all the subject of philosophy because as Augustine affirms "the true philosopher is the lover of God" (Augustine 1980, p. 298). In spite of the fact that philosophy is not identified with knowledge of God, it is obliged to Christian theology in what concerns its rationality. It is because of this obligation that one could develop theo-logia, that is knowledge of God whose foundation comes from God himself. In this sense faith has its duty with respect to reason because it has duty with respect to itself. (See (Marion 2010[2], pp. 17-29).

37 See a book of (Albert 1992) where its author develops an idea of critical methodology of knowledge with following from there criticism with respect to theology.

38 See, for example, H. Küng's response to Albert's critical assessment of theology in its pretension for rationality in (Küng 1978, pp. 324-39, 439-51).

39 The scholars of Husserl pointed out that Husserl never talked about religion, God and mysticism explicitly in his published works. Mall lists four books which concern with religious matters: The Crisis of the European Sciences, Erste Philosophie (Part 1), Zur Phänomenologie der Intersubjektivität, Vols. 1-2. Husserl, nevertheless, discusses religious issues in his unpublished manuscript. See details in (Mall 1991, p. 1). Assessing Husserl's tension between his attitude to the problem of God as being the founder of phenomenology, on the one hand, and being a Christian believer, on the other, Mall states that "the chasm between the God of phenomenology and that of theology remains unbridged till it is bridged either by a fulfilment of intended meaning of the concept of God or the reality of God makes its entrance unto human consciousness via the routes of a mystic experience, revelation, faith or grace. The path phenomenology has legitimately to traverse is only the former one and not the latter. Husserl might have reconciled the two in his own person. But that's a different story, then..." (p.13). See also a book of (Housset 1997, pp. 265-290), where the reader will be able to find a comprehensive bibliography on Husserl's involvement in religious issues; as well as a book of (Bello 2009).

40 In order to clarify the sense of what is meant by this, it is worth quoting T. Torrance where he refers to the question posed by K. Barth: "How do we come to think, by means of our thinking, that which we cannot think at all by this means? How do we come to say, by means of our language, that which we cannot say at all by this means?" There is always remains incongruence between God at the known and man as the knower. However, if the knowledge of God is to take place it must rest upon reality and grace of the object known. In this case the reality of things reveals itself to us and acts in us even in that case when the link between our knowledge and language is irreducible to the intrinsic relations between thought and speech. "we are, therefore, restricted to the harp alternatives: either to be entirety silent, that is not even to venture the sceptical question... as in regard to the rationality of nature or the laws of thought...; or to ask question only within the circle of the knowing relationship in order to test the nature and possibility of the rational structures within it" (Torrance 1997, pp. 54-55). Rephrasing this in terms of postmodern philosophical theology, how one can speak of the transcendent? Or, in other words, how can one speak of that which is incongruent with language and orders of conceptual thinking? How can one conceptualise that which is intrinsically non-conceptual, pre-conceptual or pre-theoretical? Will not be any speaking about phenomena whose phenomenality does not allow to be conceptualised a sort of violence and distortion with respect to these phenomena, reducing their phenomenality to the circle of immanent consciousness and, thus, depriving them of their otherness, that is if that which is retained in them beyond their phenomenalisation by consciousness? See, for example, (Marion 2002), (Smith 2002).

${ }^{41}$ On the dimensions of a neo-Patristic synthesis in the dialogue between theology and science see Nesteruk, The Universe as Communion.

42 This implies, according to Fr. D. Staniloae, that "any progress in understanding dogma depends in part on the progressive understanding that science has of the world", however, and here he accentuates the theological commitment, "theological thinking cannot be separated from spirituality" and this is the reason why Orthodox theology "takes scientific progress 
into account only in so far as science makes a contribution to the progress of the human spirit, and only in so far as it deepens in man the experience of his own spiritual reality and of the supreme spiritual reality...." (Staniloae 1980, p. 216).

43 Here our position is reminiscent to some ideas from the so call "Radical Orthodoxy" theological movement. See, for example, a volume on the dialogue between Eastern Orthodoxy and "Radical Orthodoxy" (Pabst, Schneider 2009).

44 A hypostatic human being appears to itself without controlling the conditions of its contingent appearance but attempting to phenomenalise it through the flow of life as directed to the future. In different words, subjectivity is extended here towards a non-intentional immanence, or reversed intentionality where the ego finds itself subject $t o$, but not subject $o f$, a givenness. The $I$ no longer precedes the phenomena that it constitutes but is instead called into being as the one who receives this intentionality. The sense of the $I$ is driven not by preconceived forms of subjectivity but by events whose sense is not immediately accessible to subjectivity but unfolds in time: the more we progress in time in seeing the universe, the more we comprehend the sense of its past; the more we grow in our life, the more sense we constitute out of the fact of our coming into being.

\section{References}

1. Albert, H., Treatise on Critical Reason (Princeton: Princeton University Press, 1992).

2. Augustine, City of God, Trans. D. Knowles (New York: Penguin Books, 1980).

3. Athanasius of Alexandria, Contra gentes, in eds. P. Schaff and H. Wace The Nicene and PostNicene Fathers, series 2, vol. 4, (Grand Rapids, MI: W. B. Eerdman Publishing Company, 1996).

4. Bello, A., The Divine in Husserl and Other Explorations, Analecta Husserliana XCVIII (Dordrecht: Springer, 2009).

5. Berdyaev, N., Slavery and Freedom (London: Centenary, 1944).

6. Berdyaev, N. A., "Man and Machine", Voprosy Filosofii, no. 8 (1991), pp. 147-62 (in Russian).

7. Clement of Alexandria, The Stromatata, or Miscellanie, in A Roberts and J Donaldson (eds.), The Ante-Nicene Fathers, vol. 2, (Grand Rapids, MI: W.B.Eerdman Publishing Company, 1962).

8. Coplestone, F., A History of Philosophy, Vol. II, Medieval Philosophy: Augustine to Scotus (London: Burns Oates \& Washbourne Ltd., 1950).

9. Heidegger, M., Nietzsche. Volume IV: Nihilism (San Francisco: Harper, 1997).

10. Clément, O., Le Christ Terre des Vivants. Essais Théologiques Spiritualite Orientale, n. 17 (Bégrolles-en-Mauges: Abbaye de Bellfontaine, 1976).

11. Comte-Sponville, A., L'esprit de l'athéisme. Introduction à une spiritualité sans Dieu (Paris: Albin Michel, 2006).

12. Dawkins, R., The God Delusion (London: Black Swan, 2007).

13. Filaret (Metropolotan), The way of the life-asserting love (Kiev: Duh I Litera, 2004)(in Russian).

14. Goutner, G., "The Unity of Humanity in an Eschatological Perspective." In Theology of Creation, ed. A. Bodrov, M. Tolstoluzhenko, (Moscow: St. Andrew's Biblical and Theological Institute, 2013), pp. 230-36 (in Russian).

15. Gurwitsch, A., Studies in Phenomenology and Psychology (Evanston: Northwestern University Press, 1966).

16. Halvorson, H., Kragh, H., "Theism and Physical Cosmology", in The Routledge Companion to Theism, ed. S. Goetz et al. (London: Routledge, 2012), pp. 241-55.

17. Heidegger, M., Nietzsche. Volume IV: Nihilism (San Francisco, Harper, 1997).

18. Housset, E., Pesonne et sujet selon Husserl (Paris: Presses Universitaires de France, 1997).

19. Husserl, E., The Crisis of European Sciences and Transcendental Phenomenology (Evanston: Northwestern University Press, 1970). 
20. Husserl, E., Ideas Pertaining to a Pure Phenomenology and to a Phenomenological Philosophy. First Book. General Introduction to a Pure Phenomenology, trans. F. Kersten. (Dordrecht: Kluwer Academic Publishers, 1998).

21. Janicaud, D., Le tournant théologique de la phénoménologie française (Combas: Éditions de l'éclat, 1990).

22. Jaspers, K., Weltgeschichte der Philosophie. Einleitung. (Munchen: R. Piper \& Co. Verlag, 1982).

23. Kierkegaard, S., Repetition and Philosophical Crumbs, trans. M. G. Piety (Oxford: Oxford University Press, 2009).

24. Krauss, L. M., A Universe from Nothing (New York: Free Press, 2012).

25. Küng, H., Does God Exist? An Answer for Today (London: SCM, 1978).

26. Ladrière, J., Language and Belief (Dublin: Gill and Macmillan, 1972).

27. Larchet, J.-C., La Divinisation de l'homme selon Saint Maxime le Confesseur (Paris, Les Editions du Cerf, 1996).

28. Leslie, J., The End of the World: The Science and Ethics of Human Extinction (New York: Routledge, 1996).

29. Levinas, E., Time and the Other (Pittsburgh: Duquesne University Press, 1987).

30. Lossky, V. N., The Mystical Theology of the Eastern Church (London: James Clarke, 1957).

31. Mall, R., "The God of Phenomenology in Comparative Contrast to that of Philosophy and Theology", Husserl Studies 8 (1991), pp. 1-15.

32. Marcel, G., Du Refus a l'Invocation (Paris, Galllimard, 1940).

33. Marcel, G., Being and Having, (London: Collins, 1965).

34. Marion, J.-L., In Excess. Studies of Saturated Phenomena (New York: Fordham University Press, 2002).

35. Marion, J.-L., Certitudes négatives (Paris, Bernard Grasset, 2010).

36. Marion, J.-L., "La foi et la raison", Le croire pour le voir. Réflexions diverses sur la rationalité de la révélation et l'irrationalité de quelques croyants (Paris: Editions Parole et Silence, 2010).

37. Natanson, M., "Being-in-Reality", Philosophy and Phenomenological Research 20, no. 2 (1959).

38. Nellas, P., Deification in Christ. Orthodox Persepectives on the Nature of the Human Person (Crestwood: St. Vladimir's Seminary Press, 1997).

39. Nesteruk, A., The Universe as Communion (London: T\&T Clark, 2008).

40. Nesteruk, A. V., "The Universe as a Saturated Phenomenon: The Christian Concept of Creation in View of Modern Philosophical and Scientific Developments", Theology and Science 12, no. 3, 1014, pp. 236-59.

41. Pabst, A., Schneider, C., (eds.), Encounter Between Eastern Orthodoxy and Radical Orthodoxy. Transfiguring the World Through the Word, (Farnham: Ashgate, 2009).

42. Pascal, B., Pensées. Selections. Trans. \& ed. Martin Jarret-Kerr (London: SCM, 1959).

43. Pascal, B., Pensées, Trans. Louis Lafuma (Paris: Ed. Du Seul, 1962).

44. Planck, M., "Religion und Naturwissenschaft". Vortag gehalten im Baltikum (Mai 1937) von Dr. Max Planck, 2te unveränd. Auflage. Joh. Ambrosius Barth Verl. Leipzig, 1938.

45. Primack, J., Abrams, N. E., The View from the Centre of the Universe. Discovering our Extraordinary Place in the Cosmos (London: Fourth Estate, 2006). 
46. Ratzinger, J., Wesen und Auftrag der Theologie (Freiburg: Johannes Verlag Einsiedeln, 1993).

47. Rees, M., Our Final Century, A Scientist's Warning: How Terror, Error, and Environmental Disaster Threaten Humankind's Future in This Century - On Earth and Beyond (London: W. Heinemann, 2003).

48. Shakhovskoi, J., (Archbishop), On the Mystery of Human Life (Moscow: Lodiya, 2003) (in Russian).

49. Sherrard, Ph., The Rape of Man and Nature: An Enquiry into the Origins and Consequences of Modern Science (Suffolk: Golgonooza, 1991).

50. Smith, J. K., Speech and Theology. Language and the logic of incarnation (London: Routledge, 2002).

51. Staniloae, D., Theology and the Church (Crestwood: St. Vladimir's Seminary Press, 1980).

52. Stenger, V. J., God the Failed Hypothesis: How Science Shows that God Does not Exist, (New York: Prometheus Books, 2008).

53. Thunberg, L., Microcosm and Mediator: The Theological Anthropology of Maximus the Confessor (Chicago: Open Court, 1995).

54. Torrance, T., Space, Time and Incarnation (Edinburg, T\&T Clark, 1997).

55. Torrance, T., The Grammar of Theology: Consonance between Theology and Science (Edinburgh: T\&T Clark, 2001).

56. Walker, A., Different Gospels (London: Hodder \& Stoughton, 1988).

57. Yannaras, C., Postmodern Metaphysics (Brookline, MS: Holy Cross Orthodox Press, 2004).

58. Yannaras, C., "The Church in Post-Communist Europe", in The Meaning of Reality. Essays on Existence and Communion, Eros and History (Los Angeles: Sebastian Press \& Indiktos, 2011), pp. $123-43$. 


\title{
Смысл Вселенной:
}

\section{к новому феноменологическому повороту \\ в диалоге между космологией и богословием}

\author{
A.В. Нестерук \\ Университет Портсмута \\ Лайон Гэйт Бюлдинг \\ ПОРТСМУТ, РОІ ЗНF, Великобритания
}

В статье обсуждается проблема интерпретаиии представлений о Вселенной как иелого в космологии в контексте современного диалога между наукой и религией. Показывается, что сама возможность функционирования как космологии, так и богословия подразумевает их имплицитную включенность друг в друга. Таким образом, иентральной проблемой диалога становится человек с его двойственной позицией в мире как органического существа, так и артикулирующего сознания всей Вселенной. Показывается несимметричность отношений между наукой и богословием и развивается идея богословского осмысления космологии, исходя из первичности факта жизни по отношению к возможности представлений о Вселенной. Обосновывается феноменологическая методология деконструкиии "представлений" о Вселенной с иелью нахождения источника базовых идей о ней в человеческой личности.

Ключевые слова: богословская преданность, вера, Вселенная, диалог, космология, личность, наука, религия, свободное мышление, человек.

Научная специальность: 09.00.00 - философские науки. 